Historia Slavorum Occidentis

2019, $\mathrm{nr} 4$ (23)

ISSN 2084-1213

DOI: $10.15804 /$ hso190403

\author{
Ondřej Felcman (Hradec Králové) \\ Tomáš Hradecký (Hradec Králové)
}

\title{
Parlament a parlamentarismus v budování a proměnách československé státnosti
}

Słowa kluczowe: Czechosłowacja, państwowość, parlamentaryzm, Zgromadzenie Narodowe, konstytucja, federacja, okres międzywojenny, lata sześćdziesiąte

Keywords: Czechoslovakia, statehood, parliamentary movement, National Assembly, constitution, federation, Interwar period, 1960s

\begin{abstract}
The study focuses on the importance of the Parliament's involvement in construction of the Czechoslovak state. With the exception of the German occupation, as the legislature of the Czechoslovak Republic, the National Assembly played an important role in affecting its republican and democratic character. The article discusses two of the most important stages of the formation of the Czechoslovak statehood. First is the Interwar period when the Czechoslovak statehood demonstrated features typical of parliamentary democracy with assumed parliamentary power, followed by the 1960s when the common state of the Czechs and Slovaks developed on a federal level.
\end{abstract}

Československý stát se po celou dobu své existence vyznačoval silným př́iklonem k parlamentní tradici. Již od počátku státu byla existence československého zákonodárného sboru základním stavebním kamenem nového politického prostředí, které spoluvytvářelo podobu státní politiky. V duchu klasického parlamentarismu bylo postavení parlamentu ústavně zakotveno; dvoukomorové Národní shromáždění 
bylo v československé parlamentní demokracii nejvyšším orgánem státní moci. Až do let nacistické okupace „státoprávně posvěcené“ zřízením Německem ovládaného Protektorátu Čechy a Morava přispíval parlament k podobě Československa jako moderního státu, jehož demokratický charakter byl přes všechny nešvary a různé politické aféry nezpochybnitelný. Jeho slabinou však byly složité národnostní poměry; především idea čechoslovakismu, která byla nutným stavebním kamenem v počátcích budování státu, se ve třicátých letech již přežívala a oslabovala sílu státní moci.

Poválečná obměna státu a parlamentu měla pak přivést na svět zcela jiné pojetí státnosti i parlamentarismu Československé republiky. Na jedné straně došlo k úpravám pojetí základní myšlenky státní stavby, když historicky překonaný čechoslovakismus byl vystř́idán koncepcí státu Čechủ a Slováků, na druhé straně ani ne tři roky po osvobození se změnila povaha státu, který po ovládnutí komunistickou stranou ztratil svou demokratickou tvár a nabyl podoby komunistické diktatury. Monopol moci KSČ trval až do roku 1989, ale v šedesátých letech se komunistická politika proměňovala a stát $s$ prvky totalitarismu postupně připouštěl prvky jisté demokratizace, odmítající rigidní třídní přistup z let stalinismu. $V$ době reformy za tzv. Pražského jara stát na krátkou dobu ztratil zcela povahu byrokratické diktatury sovětského typu. Dokonce se přes trvající vedoucí roli KSČ demokratizoval $s$ respektem $k$ humanistickým tradicím předválečné československé demokracie. Současně se vznikem České národní rady byla vytvořena do té doby neexistující česká státnost, zatímco slovenská se z řady důvodů a nejen pro tradici trvající od Slovenského národního povstání ve společném československém federálním státě zcela naplnila. Při těchto proměnách sehrálo důležitou roli také Národní shromáždění.

Studie se zaměruje na dvě z fází československé státnosti. Jednou je meziválečné období, v němž československá státnost vykazovala základní znaky parlamentní demokracie s rozvinutou mocí parlamentu. Druhou léta 1960-1969, kdy se společná státnost Čechů a Slováků vyvinula až do federativního stupně.

Československý parlamentarismus je historickým fenoménem, který nemohl být $\mathrm{v}$ minulosti opomenut $\mathrm{v}$ odborné literatuře. Již meziválečná republika si byla vědoma jeho významu a reflektovala jej v dobovém pohledu. $\mathrm{Z}$ prvorepublikových autorů lze vyzdvihnout poučený žurnalistický pohled Ferdinanda Peroutky, který se 
ve svém Budování státu ${ }^{1}$ otevřeně hlásí $k$ přísně demokratickému postoji, a je proto konstruktivně kritický $\mathrm{k}$ soudobé politické scéně. $\mathrm{V}$ parlamentu vidí především pojistku demokracie, která měla kořeny v převratné době, a k jejíž činnosti byl nutný všeobecný konsenzus nastupujících politických elit.

Pohled na zákonodárný sbor přinesli také právníci, kteří analyzovali činnost zákonodárných sborů a etapy jejich vývoje. Ucelenou deskripci Národního výboru československého představil např. Vratislav Kalousek ${ }^{2}$, který si všímal především státoprávní a státotvorné role tohoto revolučního orgánu a viděl v něm př́mého předchůdce československé parlamentní tradice. Z hlediska filosofie práva a státu se k obecným konsekvencím parlamentarismu vyjádřil ve své vysokoškolské učebnici vlivný právní odborník František Weyr ${ }^{3}$. Samotní politici meziválečného Československa pak ve svých textech či memoárech ${ }^{4}$ viděli parlament především jako základní prvek československé demokracie. Soudobý pohled celkově nezastíral, že československá demokracie a její parlamentarismus mají své chyby. Jejich výskyt byl ovšem viděn převážně v rychlosti, $\mathrm{s}$ kterou musel nový stát legislativní orgán zř́dit. Lze soudit, že léta 1918-1920 byla již za první republiky považována za období přechodné, sloužící ovšem k upevnění legitimity parlamentu a k jeho trvalému ukotvení $\mathrm{v}$ československém státě a politice.

Po druhé světové válce došlo ke změně historického náhledu, v němž byla předválečná demokratická republika popisována jako buržoazní a protilidová. V období vlády Komunistické strany Československa se proto téma parlamentarismu meziválečného státu z československé historiografie vytrácelo. Teprve po roce 1989 bylo možné $\mathrm{k}$ tomu fenoménu nově vědecky přistoupit. $\mathrm{V}$ posledních třiceti letech tak vzniklo několik velkých syntéz, které se věnují meziválečnému období Československé republiky. V něm samozřejmě má své místo také činnost Národního shromáždění. I když doposud nebyla vytvořena ucelená monografie, která by se zabývala pouze dějinami parlamentu, vytvořilo několik historiků důležité př́spěvky $k$ vývoji československé politiky po roce 1918. K zakladatelskému období Československa

1 F. Peroutka, Budování státu, díl I., Praha 2003.

2 V. Kalousek, Národní výbor, [in:] E. Hácha et al., Slovnik veřejného práva československého, svazek II., Brno 1932, s. 786-793.

3 F. Weyr, Základy filosofie právní, Brno 1920.

4 A. Rašín, Paměti Dra Aloise Rašína, ed. L. Rašín, Praha 1929 (dostupné online: http://kramerius4.nkp.cz/search/i.jsp?pid=uuid:a694016d-83f0-4f1d-9e20-2be43d78081f, 27.08.2019) 
se vyjádřili svými publikacemi Josef Hotmar ${ }^{5}$, Antonín Klimek ${ }^{6}$ a Karel Schelle kteří shodně považují Národní výbor československý za první fázi státního parlamentarismu. Zajímavým pohledem na státoprávní vývoj státu jsou bezesporu také biografie významných politiků, zakladatelů státu, kteří $\mathrm{k}$ definici československého zákonodárství svou činností výrazně přispěli ${ }^{8}$. Vlastnímu parlamentnímu tělesu pak věnují větší pozornost rozsáhlé syntézy $k$ dějinám první republiky ${ }^{9}$, především z pera Antonína Klimka ${ }^{10}$, Zdeňka Kárníka ${ }^{11}$, Věry Olivové ${ }^{12}$ či Evy Broklové ${ }^{13}$. Tyto monografie přinášejí nejen popis vlastního vývoje parlamentu, ale i širší souvislosti národnostní otázky, které s československým parlamentarismem přímo souvisely a definovaly některé krize státní politiky.

Širší problematika politického systému, který se proměňoval již v letech poválečné národní revoluce a dalšími výraznými změnami prošel po únorovém převratu $\mathrm{v}$ roce 1948, přičemž ztratil charakter parlamentní demokracie, je předmětem stálého zájmu historiků, politologů i právníků. Je řešena v bezpočtu studií, monografií, syntéz, přehledových publikací i vysokoškolských učebnic. Jedním z frekventovaných témat jsou volební systémy a praktický vývoj voleb v letech tzv. Třetí republiky (1946, 1948), v období komunistického režimu (1948-1989), ale nově již i po obnovení pluralitní demokracie po roce $1989^{14}$.

Naproti tomu téma parlamentu a parlamentarismu je téměř neznámé. Celkově není téma pro celé období vůbec pojednáno; výjimkou je menší publikace připra-

5 J. Hotmar, Zrození republiky 1914-1918, Brno 2005.

6 A. Klimek, ̌̌íjen 1918: vznik Československa, Litomyšl 1998.

7 K. Schelle, Vznik Československé republiky 1918: k 90. výročí vzniku Československé republiky, Ostrava 2008.

8 E. Broklová, Antonín Švehla - Tvưrce politického systému, Praha 2017; J. Šetřilová, Alois Rašín. Dramatický život českého politika, Praha 1997.

9 Srov. např. kol., První republika 1918-1938, Praha 2015.

10 A. Klimek, Velké dějiny zemí Koruny České, XIII., Praha-Litomyšl 2000.

11 Z. Kárník, České země v ére první republiky (1918-1938), dîl první (1918-1929), Praha 2003.

12 V. Olivová, Dějiny první republiky, Praha 2000.

13 E. Broklová, Československá demokracie: politický systém ČSR 1918-1938, Praha 1992.

14 J. Filip, K. Schelle, Vývoj a současnost voleb a volebního práva v ČSFR, Brno 1992; J. Kocian, V. Smetana a kol., Květnové volby 1946 - volby osudové? Československo před bouř́, Praha 2014; L. Vykoupil, Volby v květnu 1946, [in:] Československo na rozhraní dvou epoch nesvobody: sborník z konference $k$ 60. výročí druhé světové války, eds. Z. Kokošková, J. Kocian, S. Kokoška, Praha 2005. 
vená několika autory a zahrnující český a československý parlamentarismus od 19. století ${ }^{15}$. Obdobně to je s reflexí komunistických ústav, kde se projevuje určitý zájem jen u právníků, nikoliv však historiků. Poněkud více pozornosti se dostalo činnosti Národního shromáždění v letech československé reformy, tedy tzv. Pražského jara (1968-1969 ${ }^{16}$. Zatím zřejmě jedinou monografickou, rozsáhlejší prací v československé historiografii, která se systematicky na uvedené téma zaměřila, je monografie o působení parlamentu ve IV. volebním období od června 1964 až po volbu jeho nového vedení v dubnu $1968^{17}$. K dispozici je také tř́svazková edice editorů Františka Cigánka a Ondřeje Felcmana ${ }^{18}$. Jen rámcově v souvislosti s rozborem povahy komunistického politického systému je omezená role parlamentního sboru dotčena v jiných publikacích ${ }^{19}$.

Větší zájem historici projevili o vývoj názorů na česko-slovenské vztahy, které měly v některých letech krizové parametry (tři pražské dohody, vývoj slovenské autonomie v padesátých a šedesátých letech, príprava federace), což se odráželo v interpretační rovině jednotlivých pracíi ${ }^{20}$. Synteticky a s nadhledem zpracoval téma

15 V. Doubek, M. Polášek a kol., Parlament v čase změny. Př́padové studie $z$ vývoje českého a československého parlamentarismu, Praha 2011.

16 F. Cigánek, Postavení a role parlamentu v srpnových dnech roku 1968, [in:] Promèny pražského jara. Sborník studií o nekapitulantských postojích v československé společnosti 19681969, Praha - Brno 1993, s. 123-164; O. Felcman, Postoj Národního shromáždèní k volbám do národních výborů na jaře 1968, [in:] Semper idem, Jiřímu Tưmovi k pětasedmdesátinám, ed. Z. Radvanovský, Ústí nad Labem, UJEP 2003, s. 131-138; idem, Československé Národní shromáždèní v roce 1968, [in]: Dvacáté století/The Twentieth Century, roč. 2009, č. 1, s. 151-159; Idem, Národní shromáždèní a jeho podíl na rozrušování sovětského modelu socialismu $v$ Československu, [in:] M. Londák, S. Sikora a kol., Rok 1968 a jeho miesto v našich dejinách, Bratislava 2009, s. 140-161.

17 O. Felcman, Československý parlament na prahu Pražského jara. Národní shromáždění na cestě $k$ reformè (1964 - duben 1968), Praha 2015.

18 F. Cigánek, Národní shromáždění, ediční řada prameny k dějinám československé krize v letech 1967-1970, 3, díl, 2. svazek: 21. - 28. srpna 1968, Praha-Brno 1995; Srov. F. Cigánek, O. Felcman (vyd.), Národní shromáždění, Ediční řada Prameny k dějinám československé krize v letech 1967-1970, 3. díl, 1. svazek: Květen 1967 - červenec 1968, Praha-Brno 2002 a titíž, 3. díl, 3. svazek: Srpen 1968 - leden 1969, Praha-Brno 2009.

19 K. Kaplan, Kořeny československé reformy 1968, díl III-IV, Brno 2002, s. 205-210.

20 S. Faltan, Slovenská otázka v Československu, Bratislava 1968; V. Plevza, Československá štátnost' a slovenská otázka v politike KSČ, Bratislava 1971; S. Matoušek, Vznik a vývoj společného státu Čechů a Slovákü, Praha 1980; K. Kaplan, Pravda o Československu 1945-1948, Praha 1990, s. 159-192; M. Londák, S. Sikora, E. Londáková, Predjarie: Politický, ekonomický a kulturní vývoj na Slovensku v rokoch 1960-1967, Bratislava 2002. 
Jan Rychlík ${ }^{21}$. Skutečně hlubší rozbor nabízejí především práce slovenských autorů, kteří věnují postavení Slovenska v komunistickém Československu značnou pozornost ${ }^{22}$. Přirozeně mnoho úsilí bylo zaměřeno na poznání prípravy federalizace státu a jejího uvedení $\mathrm{v}$ život ${ }^{23}$. $\mathrm{K}$ dispozici je např́ílad dvojdílná edice o př́ípravě federace od J. Žatkuliaka ${ }^{24}$.

Pro poznání těchto vztahů jsou důležité i práce, zachycující vývoj státností obou národů československého státu - slovenské a české. Zatímco k působení SNR bylo věnováno již poměrně velké množství studiii ${ }^{25}$, pro poznání ČNR - a to ještě v krátké fázi po jejím vzniku v době reformních změn roku 1968 a jejich následného utlumování a poté prímé likvidace - je zatím k dispozici pouze studie Zdeňka Jičínského ${ }^{26}$. Lze předpokládat, že se postupně rozvine zájmem o hlubší poznání politického vývoje poválečného Československa a rovněž výzkum těchto aspektů státnosti a parlamentarismu. Archivní dokumentace a odborný dobový tisk k tomu vybízejí.

21 J. Rychlík, Češi a Slováci ve 20. století. Česko-slovenské vztahy 1945-1992, Praha 1998.

22 Práce aktuálně reagující na prrípravu a realizaci federalizace a odrážející i dobovou atmosféru, nejprve reformní, poté normalizační - srov. J. Barto, Riešenie vzt'ahu Čechov a Slovákov 1944-1948, Bratislava 1968 a V. Plevza, Československá štátnost a slovenská otázka v politike KSČ, Bratislava 1971. Z prací vzniklých po rozpadu Československa lze uvést např. M. Barnovský (ed.), Slovenská národná otázka v dějinách Česko-Slovenska (1945-1992), Bratislava 1994 nebo M. Londák, S. Sikora, E. Londáková, Predjarie: Politický, ekonomický a kulturny vývoj na Slovensku v rokoch 1960-1967, Bratislava 2002.

23 R. Trella, J. Chovanec, Nové štátoprávne usporiadanie ČSSR, Bratislava 1971; J. Žatkuliak, Realizácia ústavného zákona o československej federácii od októbra 1968, Historický Časopis 40, 1992, č. 3, s. 356-369; idem, Deformácie ústavného zákona o československej federácii od októbra 1968, Historický časopis 40, 1992, č. 4, s. 473-486.

24 J. Žatkuliak (vyd.), Federalizácia československého štátu 1968-1970, ediční řada Prameny k dějinám československé krize v letech 1967-1970, 5. díl, 1. sv.: Vznik česko-slovenskej federácie 1968, Praha - Brno 1996; dále týž, Realizácia a normalizačná revízia česko-slovenskej federácie (september 1968-december 1970). Dokumenty, Praha 2011.

25 E. Rákoš, Š. Rudohradský, Slovenské národné orgány v rokoch 1943-1968, Bratislava 1973; dále stati ve sborníkové publikaci J. Žatkuliak (ed.), Národná rada v kontexte slovenských dejín. 150. výročie vzniku prvej Slovenskej národnej rady, Bratislava 1999; R. Pavlovič, Slovenská národná rada 1948-1968, [in:] České, slovenské a československé dějiny 20. století. Osudové osmičky v našich dějinách, edd., J. Mervart, J. Štěpán a kol., Hradec Králové 2008, s. 341-354.

26 Z. Jičínský, Vznik České národní rady v době Pražského jara 1968 a její působení do podzimu 1969, Praha 1990. 


\section{I.}

Vznik Československa v roce 1918 byl prímo spojen se zrodem tradice československého parlamentarismu. Čelní zakladatelé nového státního útvaru již od počátku dbali na vytvoření nezávislého zákonodárného sboru, který vzejde z řádných voleb. Situace v druhé polovině roku 1918 byla však složitější. Československá politická reprezentace, toužící po samostatnosti, byla rozdělena mezi domácí a zahraniční protirakouský odboj. Vzájemná komunikace obou skupin autonomistů byla v důsledku končící války značně omezena, a tak jejich možnost vytvořit parlament nového státu narážela na mnohé limity. V ř́jnových dnech roku 1918 bylo zcela nemožné pořádat parlamentní volby. Stát ještě nezískal pevné obrysy geografické ani politické, situace v národnostní otázce byla nepřehledná, nekonstituovala se pevná pravidla politické soutěže, nebyla vydána ústavní listina. Všechny ty to otázky měly být teprve řešeny, což ale bez zákonodárného sboru nešlo. Jediný způsob, jakým bylo možné postupovat, bylo sestavit zákonodárný sbor prozatímně. Tzv. protoparlamentární ${ }^{27}$ fáze československého státního vývoje poskytla státu pro budoucno silný stabilizační prvek, který se mohl později bez větších obtíží transformovat v řádný parlament Československé republiky. V této vývojové fázi se pracovalo s jednoduchou, avšak velmi účinnou tezí. Revoluční orgány nového státu budou transformovány do podoby zákonodárného sboru, jehož hlavním úkolem bude vypracovat ústavu, která definuje stát ve všech nezbytných oblastech. Podle nového ústavního pořádku měly být poté vypsány řádné demokratické volby, z nichž měl vzejít volený parlament. Všechny tyto kroky měly být provedeny v pokud možno co nejkratší době, nebot'

27 Definice protoparlamentu (či přípravného parlamentu, před-parlamentu ... ), tedy prozatímního orgánu, který nese rysy zákonodárného sboru, je však časově i funkčně limitován a přestavuje jen první vývojovou fázi na cestě $\mathrm{k}$ ústavnosti a řádnému parlamentu, není v historiografii střední Evropy ustálená. V německém prostředí je jako „Vorparlament“ jmenován téměř výhradně sněm volených zástupců z členských států Německého spolku, který se sešel v květnu 1848 ve Frankfurtu nad Mohanem. S Národním výborem československým z roku 1918 pojí německý Vorparlament př́ipravy konstituce, nikoli však obecně přijímaná dočasnost. Název „Pseudo-Parlament“" se pak používá spíše pro nefunkční, již konstituované zákonodárné sbory v totalitních nebo pretotalitních režimech. K Vorparlamentu srov. M. Botzenhart, Deutscher Parlamentarismus in der Revolutionszeit 1848-1850, Düsseldorf 1977; k pseudo-parlamentarismu srov. A. Burkhardt, German Parliamentary Discourse since 1848 from a Linguistic Point of View, [in: ] P. Ihalainen et al., Parliament and parliamentarism. A Comparative History of a European Concept, New York-Oxford 2016, především s. 184 an. 
demokraticky založení zakladatelé státu si uvědomovali, že jde o fázi přechodnou.

Za prvního představitele československého parlamentarismu lze považovat Národní výbor československý (NVČs) ${ }^{28}$, který započal svou práci ihned se vznikem samostatného státu 28. X. 1918. Výbor byl považován za jediného vrcholného reprezentanta českých politických elit ${ }^{29}$, zejména poté, co se mnoho obdobných institucí, sdružující politiky české národnosti, za světové války politicky zdiskreditovalo ${ }^{30}$. Základní otázkou však bylo personální uspořádání NVČs. Nadšený duch převratné doby velel, aby byla dodržována kontinuita všech demokratických prvků, které byly do politiky Rakousko-Uherska implementovány. Podle návrhu Antonína Švehly ${ }^{31}$ (tzv. Švehlův klíč) zrcadlilo složení osmatřicetičlenného sboru zisky českých politických stran z posledních předválečných voleb do Říšské rady v roce $1911^{32}$. Švehla měl pro tento návrh dobrý důvod. Od zavedení rovného volebního práva v Rakousko-Uhersku ${ }^{33}$ mohli čeští muži volit své poslance rovnými hlasy, bez ohledu na svůj původ, finanční zázemí nebo společenské postavení. Prvními volbami tohoto typu byly volby do Říšské rady z května 1907. V nich došlo k odstranění starého kuriálního systému, nicméně ani tento nový systém nepřinesl úplnou rovnost volebního práva. Kromě eliminace žen z volebního procesu nebyl výrazněji rekonstruován systém volebních obvodů, které se stále dělily na městské a venkovské obvody. Ty nebyly stejně velké a ke zvolení jednoho poslance tak bylo zapotřebí rozdílného počtu

28 Národní výbor československý (NVČs) vznikl již 13 VII 1918 jako orgán, který se systematicky připravoval na převzetí moci v novém státě.

29 Podobně uvažuje o Národním výboru československém i F. Peroutka, Budování státu I., s. 12. K recepci Národního Výboru dále srov. V. Kalousek, Národní výbor, s. 786-793.

30 Jde především o předchůdce NVČs, tzv. Národní výbor, založený v roce 1916 coby organizace českých politických stran. Kvůli svému loajálnímu postoji vůči Rakousko-Uhersku byl však nucen svou existenci v roce 1917 pozastavit. Srov. Z. Kárník, České země v éře první republiky I, s. 19 an. Dalším příkladem zdiskreditované české politické organizace, řadící se mezi loajální prorakouská sdružení, budiž i Český svaz, sdružující poslance Ř́šské rady. Srov. F. Peroutka, Budování státu I., s. 5-10, zejm. s. 9; O. Urban, Česká společnost 1948-1918, Praha 1982, s. 604 an.

31 Antonín Švehla (1873-1933) byl nejvýznamnější předseda československé agrární strany (1909-1933) a ministerský předseda za první republiky (1922-1929). Patřil k největším demokratickým oporám a konstruktérům moderní československé státní politiky. K jeho osobě nejnověji srov. E. Broklová, Antonín Švehla - Tvưrce politického systému, Praha 2017.

32 A. Klimek, Velké dějiny XIII, zejména, s. 26.

33 Gesetz vom 26 I 1907, betreffend die Wahl der Mitglieder des Abgeordnetenhauses des Reichsrates (R.G.Bl. 17/1907), \$ 4. 
hlasů, což nahrávalo především tradičním velkoměstským politickým uskupením, v nichž se uměl prosadit německý element. Jak uvádí Otto Urban: „Rozpětí mezi nejmenším obvodem se 12000 obyvateli, tj. přibližně 3000 oprávněnými voliči, a největším s 80000 obyvateli, tj. 20000 voliči, hovoř́i samo za sebe ${ }^{\text {“34. }}$. Na zvolení jednoho poslance $v$ německých obvodech tak bylo průměrně třeba 40000 obyvatel, zatímco v českých až $55000^{35}$. Čeští poslanci tak obsadili v Ř́šské radě celkem 108 křesel z 516. Mezi nejúspěšnějšími českými stranami lze uvést agrárníky (28 mandátů), „svobodomyslné a národnî (tj. Staročechy a Mladočechy, kteří společně dosáhli 26 mandátů) a sociální demokracii (24 mandátů ${ }^{36}$.

Stejného volebního systému do Ř́šské rady bylo použito i při posledních rakousko-uherských volbách na našem území v červnu 1911. Díky uspořádání volebních obvodů získala česká politická uskupení opět 108 poslanců z 516, proměnila se však politická př́slušnost nově zvolených poslanců. Menší české strany mnohdy ztratily své poslance $\mathrm{v}$ Řišské radě na úkor zisků větších politických stran, zejména v městských obvodech ${ }^{37}$. Nejvíce křesel tak obsadili agrárníci (30 mandátů), následováni národními sociály (15 mandátů), sociálními demokraty (14 mandátů) a nezávisle kandidujícími Mladočechy (14 mandátů) ${ }^{38}$.

Roku 1918 tedy Antonín Švehla navrhl, aby se při složení Národního výboru československého přihlédlo k volebním výsledkům, kterých české politické strany dosáhly v roce 1911. Vyjádřil tím důležitou myšlenku, že tyto volby vyjadřovaly vưli českého lidu ve všech jeho vrstvách; měly proto základní demokratické parametry, na které chtěl nový československý stát navázat a zachovat je i do budoucna (volby byly prrímé, rovné a tajné).

Podle tohoto klíče tak byl zvolen první zákonodárný orgán vznikajícího Československa. Národní výbor československý sestával z 38 členů, z nichž náleželo k Českoslovanské sociálně demokratické straně dělnické deset členů, České straně agrární a České státoprávní demokracii shodně po devíti členech a České straně národně sociální čtyři členové. Katolické strany měly dohromady taktéž čtyři členy, po jednom členu pak Národní strana (Staročeši) a Česká strana pokroková. Švehlův klíč

34 O. Urban, Česká společnost 1948-1918, Praha 1982, s. 530.

35 Tamtéž.

36 Národní listy, ročník 47, č. 151, 3 VI 1907, s. 1, politické zprávy domácí.

37 P. Drtina, Československo - můj osud, Praha 1991, s. 9-10, např́klad vzpomíná, že ani jeho otec, prof. dr. František Drtina, významný člen lidové (realistické) strany, svůj mandát z roku 1907 v obvodu městského okresu Hradec Králové již nedokázal o čtyři roky později obhájit.

38 Československé dějiny v datech, Praha 1987, s. 629 an. 
ovšem nesledoval přesné výsledky a pořadí stran z posledních voleb do Řišské Rady z roku 1911. Poměr mandátů v Národním výboru byl upraven na základě politického konsenzu. Tento racionální kalkul odrážel nejen povědomí politiků nového státu o nerovnosti hlasů ve volebních obvodech Rakouska-Uherska, ale také fakt, že se od posledních voleb začalo proměňovat politické spektrum. Mladočeský volební zisk byl tak nově přičten České státoprávní demokracii, která vznikla až v únoru 1918 spojením Mladočechů, Státoprávně pokrokové strany, Lidové strany pokrokové na Moravě a České strany pokrokové (realistické) ${ }^{39}$. Silný mandát sociálních demokratů v Národním výboru znamenal vědomé politické posílení české dělnické vrstvy a jejích politických předáků, kteří se po čtyřech desetiletích zápasu mohli plně a bez dalších omezení zasazovat o zájmy dělnictva v novém státě. Politická afilace 38 členů Národního výboru tak byla nejen výsledkem reflexe předválečné volební tradice, ale také povědomí o aktuálním politickém prostředí nového československého státu. Otázkou př́padného zastoupení národnostních menšin v NVČs se v převratných dnech ř́jna 1918 nikdo nezabýval ${ }^{40}$.

V tomto složení Národní výbor od 28. X. do 14. XI. 1918 přijal celkem 17 dekretů (opatření s platností zákona) ${ }^{41}$ a vypracoval koncept prozatímní ústavy. Dekrety nesou jasné znaky zrychleného vypracování i přijetí, nicméně se jednalo o důležité státoprávní prvky, které byly do fungování vyhlášeného státu implementovány.

Nejdůležitějším z těchto dekretů je jistě zákon z 28. X. 1918 o zř́zení samostatného státu československého, ${ }^{42}$ který při vyhlášení samostatnosti sepsal Alois Ra-

39 Národní listy, ročník 58, č. 32, 11 II 1918, s. 2, K organisaci strany české státoprávní demokracie. V březnu 1918 se do České státoprávní demokracie ještě vtělila část upadající Národní strany (Staročechů), jejíž formální zastoupení v NVČs tak již bylo spíše symbolické.

40 Podobněji srov. A. Klimek, Velké dějiny zemí Koruny České, XIII., Praha-Litomyšl 2000, s. 23 an.

41 Srov. dále V. Sedláček, K prvnímu tuctu zákonů přijatých takřka před sto lety, Právní Rádce, ročník 26, č. 9, 2018, s. 44-48.

42 Originál listiny uchovává Archiv Národního muzea, fond č. 298 - Alois Rašín, inv. č. 814, rukopis Zákona o zř́zení samostatného státu československého ze dne 28. X. 1918. Tiskem vyšel zákon hned další den, tj. 29. X. 1918. Srov. První zákon, Lidové Noviny, ročník 26, č. 297, 29. X. 1918, s. 1; První zákon československé vlády, Venkov, ročník 13, číslo 251, 29. X. 1918, s. 3. Jiné významné deníky, např. Národní listy, přinesly uvedeného pouze povšechnou informaci o zasedání Národního výboru. Srov. Z Národního výboru, Národní Listy, ročník 58, č. 116, 29. X. 1918, s. 1. Zákon o zřízení samostatného státu byl zařazen do sbírky zákonů Československé republiky pod číslem 11/1918 Sb. 
šín ${ }^{43}$. V zákoně jsou položeny základní fundamenty československé státnosti a charakterizované prvky nového parlamentního státu. Národní výbor se zasloužil o to, že v období po vzniku Československa neexistovalo „právní bezčasí, tedy období bez právní normativity ${ }^{44}$. Zákon prohlašoval, že právní nařízení Rakouska-Uherska zůstávají v platnosti až do chvíle, než budou nahrazena novými. Šlo o akt kontinuálního státoprávního vývoje (tzv. recepce zákonů), který umožnil emitovat další normativní právní akty na již existujícím základě 45 . Přijetí zákonů bývalého mocnářství včlenilo do československého právního systému rakousko-uherské zákony, z nichž některé zůstaly v platnosti po desítky let.

Nový zákon potvrdil vyhlášení Československa, aniž by však specifikoval jeho státní zřízení - zmiňoval pouze Československý stát ${ }^{46}$. K potvrzení republikánského zř́zení mělo dojít až po návratu delegace československých politikủ ze Ženevy, kde byla 28 . X. 1918 vyhlášena československá samostatnost paralelně ${ }^{47}$. Na základních otázkách československé státnosti se měli shodnout všichni představitelé nového státu, kteří se o jeho konstrukci zasloužili. Přesto ani po př́jezdu ženevské delegace 5. XI. 1918 nebylo republikánské zřízení Československa pevně stanoveno zákonem. Jakkoli se samožrejmě všeobecně počítalo s republikou, zmiňovaly se všechny důležité zákony do 14. XI. 1918 výhradně o československém státě.

Československý národní výbor představoval důležitou, nicméně pouze prozatímní revoluční zákonodárnou sílu nového státu. Všechny kroky zákonodárců směřovaly k ustavení širšího parlamentu, byt' se to zatím mělo obejít bez voleb. V zákoně o založení státu není ještě parlament Československa přesně definován. Československým

43 JUDr. Alois Rašín (1867-1923) byl jeden z tzv. Mužů 28. října, členů NVČs, kteří vyhlásili samostatnost Československa. Byl významný představitel Československé národní demokracie. V samostatném státě zastával post ministra financí. K jeho osobě srov. J. Šetřilová, Alois Rašín. Dramatický život českého politika, Praha 1997, a dále odkaz v pozn. 4.

44 Zákon č. 11/1918 Sb. O zřízení samostatného státu československého ze dne 28. X. 1918, čl. 2.

45 Již krátce po vzniku Československa se právní odborníci zabývali kontinuitou právní normativity. Výstižně tuto nezbytnost kontinuity právních norem popsal z hlediska filosofie práva napr. F. Weyr, Základy filosofie právní, s. 18 an. Nověji pak srov. O. Horák, Vznik Československa a recepce práva. K právní povaze a významu zákona čís. 11/1918 Sb. z. a n. s prihlédnutím k otázce recepce právního řádu, in: L. Soukup (ed.), Právněhistorické studie, ročník 38, Praha 2007, s. 153-169.

46 Zákon č. 11/1918 Sb. O zřízení samostatného státu československého ze dne 28. X. 1918, čl. 1 .

47 O vzniku Československa dále šíreji pojednává literatura v pozn. 5-7. 
politikům bylo zřejmé, že nelze vložit veškerou moc do rukou Národního výboru československého, nebot' mu byly podřízeny všechny orgány a instituce $\mathrm{v} z e \mathrm{mi}^{48}$ a sám nebyl zpočátku nikomu odpovědný. $V$ přechodné době však bylo možné přijmout nové potřebné zákony, které si převratnost chvíle vyžadovala. Demokratičnost nového státu, po níž bylo tolik voláno, vyžadovala především řešení, které podřídí činnost parlamentu širším právním normám a vytvoří československou ústavu ${ }^{49}$. Pouze ústavním zákonem bylo možné jmenovat širší parlament a do něj podle platných právních principů kooptovat nové poslance. Dne 13. XI. 1918 byl proto vydán Národním výborem zákon č. 37/1918 Sb. o prozatímní ústavě ${ }^{50}$. Definoval československý parlament - Národní shromáždění - jako jednokomorový orgán, který jako jediný měl vykonávat zákonodárnou moc v celém státě. Zajímavostí je, že ani prozatímní ústava nestanovila formu státního zřízení. O tom, že Československo bylo republikou, můžeme soudit pouze z náznaků patrných $\mathrm{v}$ jednotlivých částech prozatímní ústavy, v nichž se hovoří o hlavě státu jako o „prezidentu republiky “51, nebo o vynášení rozsudků nezávislých soudů „jménem republiky“52. Prozatímní ústava nicméně vtiskla československé státnosti podstatný princip moderního demokratického státu: oddělila od sebe zřetelně moc výkonnou (vláda), zákonodárnou (parlament) a potvrdla nezávislost soudnictví ${ }^{\prime 3}$. Určila také odpovědnost vlády Národnímu shromáždění (které vystupovalo do roku 1920 s adjektivem „Revoluční) a volbu hlavy státu tímto parlamentem ${ }^{54}$. Na prvním zasedání Revolučního národního shromáždění o den později - 14. XI. 1918 - jmenoval nový československý

48 Zákon č. 11/1918 Sb. O zř́zení samostatného státu československého ze dne 28. X. 1918, čl. 3 určuje: „Všechny ústavy samosprávné, státní a župní, ústavy státní, zemské, okresní, a zejména i obecní jsou podřizeny Národnímu výboru."

49 K potřebě ústavně podloženého rozšíření Národního výboru do širšího orgánu se z přímých účastníků událostí roku 1918 vyjadřuje např. F. Soukup, 28. ř́ien 1918, Praha 1928, díl II., zejm. s. 1068 an.

50 Zákon č. 37/1918 Sb. o prozatímní ústavě ze dne 13. XI. 1918 (též zvaný Prozatímní ústava).

51 Tamtéž, $\$ 7$.

52 Tamtéž, $\$ 13$.

53 O tzv. dělbě moci (exekutiva, exekutiva a judikativa) jako základním principu demokratického parlamentního státu se zmiňuje řada právních publikací, je rovněž tématem mnohých odborných konferencí. Srov. např. J. Jirásek (ed.), Dèlba moci. Sborník př́spèvků sekce ústavního práva, přednesených na mezinárodní vědecké konferenci Olomoucké právnické dny 2013, Olomouc 2014.

54 Zákon č. 37/1918 Sb., \$ 7 a \$16. 
parlament vládu, v jejímž čele stál Karel Kramářs5 a zpětně odsouhlasil všechny dekrety a návrhy ${ }^{56} \mathrm{NVČs} \mathrm{jako} \mathrm{platné} \mathrm{v} \mathrm{souladu} \mathrm{s} \mathrm{prozatímní} \mathrm{ústavou}{ }^{57}$.

Nový parlament měl v listopadu 1918 celkem 256 členů z různých politických stran, $\mathrm{v}$ příštím roce došlo $\mathrm{k}$ rozšíření počtu poslanců až na 270. Ke jmenování poslanců Revolučního národního shromáždění byl znovu použit Švehlův klíč. Z celkového počtu obsadila Agrární strana parlament 55 poslanci, Československá strana sociálně demokratická dělnická 53 poslanci, Československá národní demokracie předsedy vlády Kramáře si nárokovala 46 poslaneckých křesel, Československou stranu socialistickou zastupovalo 35 poslanců, Československou stranu lidovou (vzniklou sloučením českých a moravských katolických stran v roce 1919) reprezentovalo 24 zákonodárců. Kromě jmenování poslanců na základě Švehlova klíče mělo ještě dojít ke kooptaci 11 poslanců, kteří nebyli afilováni k žádné politické straně. Šlo o osoby, které se měly stát poslanci ex officio, o zástupce československých legií a dalších organizacís ${ }^{18}$.

Československo v této chvíli dospělo také k prvnímu problému. Navzdory zřejmé potřebě vyhlásit stát z vůle Čechů a Slovákư ${ }^{59}$ se ukázalo, že vzniká stát mnohonárodnostní, jehož složení by mělo Revoluční národní shromáždění reflektovat. Vzhledem ke snahám českých Němců odtrhnout se od nového státu již na přelomu řína a listopadu 1918 byl prosazen všeobecný konsenzus, který vyloučil německou politickou reprezentaci prozatímně z nového revolučního parlamentu navzdory tomu, že mnozí představitelé německé národnosti byli rádně zvolení ve volbách do Říšské rady v roce 1911 na území Čech, Moravy a Slezska. Stejným zpơsobem nebyli do parlamentu přizváni ani prŕslušníci dalších národnostních minorit Československa.

55 Společná digitální česko-slovenská parlamentní knihovna, Národní shromáždění 1918-1920, Stenoprotokoly, 1. Schůze, 14. XI. 1918 (dostupné online: www.psp.cz). JUDr. Karel Kramář (1860-1937), přední člen protirakouského domácího odboje, byl v průběhu října 1918 předsedou České státoprávní demokracie, od března 1919 pak předseda Československé národní demokracie. Byl prvním předsedou československé vlády po založení samostatného státu (do července 1919).

56 Původní návrhy Revolučního národního shromáždění jsou v rukopisné podobě blíže př́stupny v Národním archivu (NA), f. 469, č. j. 2160, kart. 643 (6 XII 1918).

57 Zákon č. 37/1918 Sb. \$ 20.

58 A. Klimek, Velké dèjiny, XIII, s. 52.

59 O vzniku státu Čechů a Slováků hovoří již Pittsburská dohoda exilových sdružení Čechů a Slováků v USA z května 1918. Navzdory tomu, že text de facto přislibuje Slovensku autonomní prvky, nebylo v prozatímní ústavě ČSR k pozici Slovenska v novém státě dostatečně přihlíženo, což vedlo brzy k prvním sporům. 
Problém nastal i se Slováky, kteří podle nového konstruktu tvořili součást československého státotvorného národa. Ti měli v rámci státní ideologie tvořit spolu s Čechy konstruktivní a politicky aktivní součást veřejné sféry státu. Netypická však byla již kooptace Slováků do Revolučního národního shromáždění. Švehlův klíč nebylo možné použít, nebot Slovensko se svým zastoupením v Uherském sněmu nemohlo rovnat síle českého politického živlu v Řiśšsé radě Předlitavska. Nedalo se tedy mluvit o vůli slovenského lidu při volbách do uherského zákonodárného sboru. Při konstrukci revolučního parlamentu bylo pro Slováky postupně vyhrazeno 45 poslaneckých mandátů ${ }^{60}$, aniž by bylo specifikováno, zda tito poslanci musí nutně patřit k nějakému slovenskému politickému směru. Široké spektrum českých politických stran a hnutí se v kontrastu s uniformním označením „slovenští poslanci“ zdálo již $\mathrm{v}$ této době v parlamentu príliš dominantním. Idea čechoslovakismu, která se stala jedním ze základních pilírư státnosti, se poprvé ukazovala jako idea centralistická. Mnozí glosátoři tvrdili, že Slováci politickou pluralitu netvoří záměrně, nebot' si zakládají na své jednotě. Tento český pohled přijal i Ferdinand Peroutka: „Nutno říci, že Slováci zatím po přesném stranickém rozestoupení ani př́liš netoužili, naopak, vyhýbali se mu ..." ${ }^{\text {". }}$. Co však slovenské politiky zajímalo, to byla parlamentní diskuse nad otázkou státní ideologie. Již v Martinské deklaraci z 30. X. 1918 bylo zdůrazněno, že Slovensko je součástí národního čechoslovakismu a připojuje se k uznání práva na sebeurčení. ${ }^{62}$ Nehovoří se v ní o „československém státě“, nicméně je patrné, že nová státnost byla založena na shodném přihlášení se obou národů k jednotné státní ideji. Z uvedených dokumentů, které vznikly na (proto)parlamentním základě československého státu, tudíž vyplývá, že státnost Čechoslováků vznikla z vưle obou národů, a ty tak mají stejné právo na disponování s politickou mocí ve státě, včetně práva na vyváženou politickou autonomii v klíčových národnostních otázkách. V této otázce tkvělo jádro postoje nacionálních Slováků, kteří se dožadovali autonomních prvků.

60 A. Klimek, tamtéž, s. 52 uvádí počet 41 k listopadu 1918, přičemž však došlo následně k rozšiřování počtu poslanců. V roce 1919 již počet Slováků v parlamentu dosáhl 45.

61 F. Peroutka, Budování státu I, s. 179. Slovensko mělo v Revolučním národním shromáždění pouze jediný poslanecký klub, tzv. Slovenský klub, který sdružoval všechny slovenské poslance.

62 Deklarácia slovenského národa, Turčianský Sv. Martin, 30. X. 1918, odst. 2. Původní verze zápisu se nedochovala, což vedlo slovenské nacionalisty k úvahám o tom, že obsahovala explicitně vyjádřené právo na sebeurčení Slovenska se všemi státoprávními znaky, které Češi odmítali. K tomu srov. Z. Kárník, České země v ére první republiky I, s. 45-46. 
Revoluční národní shromáždění však v době svého působení (1918-1920) nepřijalo žádné důsledné opatření pro vymezení slovenské autonomie nebo alespoň svébytnosti u orgánů slovenské správy. Československo zůstalo centralistickým státem, v němž existoval pouze centrální parlament, který přijímal zákony platné pro celé státní území. Československý parlamentarismus tak vykazoval jednoznačně unitární rysy. ${ }^{63}$ Občasná kritika tohoto modelu se před přijetím řádné konstituce na půdě zákonodárného orgánu neodehrávala, spíše probíhala v politickém pozadí.

Definujeme-li státnost jako zákonné a ústavní vymezení podoby státního zřizení, pak parlament Československa projevil svou iniciativu především v procesu přípravy řádné ústavy. Zákonodárci museli reagovat na nové okolnosti, které bylo třeba zohlednit. Jedním z potřebných ústavních vymezení bylo ukotvení Podkarpatské Rusi $\mathrm{v}$ rámci československého státu, která byla připojena $\mathrm{k}$ ČSR až dodatečně na základě rozhodnutí Pařižské mírové konference v průběhu roku $1919^{64}$. Do popředí se znovu dostala otázka slovenské politické reprezentace a také řešení politické angažovanosti národnostních minorit ve státě. Rádná ústava, kterou připravoval parlamentní ústavní výbor v čele s Alfrédem Meissnerem ${ }^{65}$, přinesla i další podstatné změny v definici československé státnosti ${ }^{66}$.

Když byla v přechodném dni roku 1920 (29. února) oficiálně přijata nová československá ústava ${ }^{67}$, zmizely tím z prozatímní podoby státu mnohá provizoria a dočasná řešení. $V$ prvé řadě bylo po více než roce existence nového státu definováno jeho státní zřízení: Československo se oficiálně stalo republikou ${ }^{68}$. Národní shromáždění

63 Srov. A. Klimek, Velké dějiny XIII, s. 54-55; Z. Kárník, České země v éře první republiky I, s. 109-111.

64 Připojení Podkarpatské Rusi, patřící po zániku Kyjevské Rusi Uherskému království, k Československé republice definitivně potvrdila vytyčením hranic mírová smlouva s Mad'arskem, podepsaná v Trianonu 4. VI. 1920, především část II - Hranice Mad'arska, čl. 27., (3), (4). Již před podepsáním této mírové dohody však byla v ústavě Československa z roku 1920 uvedena Podkarpatská Rus jako součást státu a byly vydány zákony ve vztahu k tomuto území. Např. tzv. jazykový zákon č. 122/1920 Sb. ze dne 29. II. 1920, podle \$ 129 ústavní listiny, jímž se stanoví zásady jazykového práva v republice Československé (jazykový zákon), zejm. \$ 1.

65 Ke složení ústavního výboru Revolučního národního shromáždění blíže srov. Z. Kárník, České země vére první republiky I, s. 99.

66 K detailním problémům vzniku první řádné československé ústavy se až později vyjádřil Z.V. Tobolka, Jak vznikla ústava Československé republiky z roku 1920, Praha 1946.

67 Oficiálně jde o zákon č. 121/1920 Sb., kterým se uvozuje Ústavní listina Československé republiky.

68 Tamtéž, hlava první, $\$ 2$. 
přijalo také zřetelně definované demokratické prvky, z nichž nejvýznamnější se týkal právě podoby československého parlamentu. Od roku 1920 bylo Národní shromáždění dvoukomorové, sestávající z Poslanecké sněmovny (300 poslanců na šestileté volební období) a Senátu (150 senátorů volených na 8 let $)^{69}$. Bikameralismus měl zajistit vícestupňovou kontrolu návrhů zákonů a rozširíit pole pro demokratickou diskusi o jejich znění.

Velkým symbolem státnosti se stal první československý prezident Tomáš G. Masaryk, kterému parlament přiřknul v nové ústavě rozsáhlé pravomoci. Nejen že mohl být zvolen prezidentem ve více než dvou po sobě jdoucích sedmiletých volebních obdobích ${ }^{70}$, ale na rozdíl od prozatímní ústavy z roku 1918 měl po roce 1920 i rozsáhlejší pravomoci. Mohl svolávat, odročovat i rozpouštět Národní shromáždění, jmenoval ministry vlády a měl rozsáhlé možnosti vracet zpět k projednání návrhy zákonů parlamentu (a později i sněmu Podkarpatské Rusi). ${ }^{71} \mathrm{Z}$ prezidenta-osvoboditele se tak stala právně nejen formální hlava státu, ale také člověk s velkou politickou mocí.

Přijetí ústavy předcházely dlouhé debaty o její demokratičnosti a principech. Zřejmými oponenty byli především členové radikální levice v sociální demokracii, budoucí českoslovenští komunisté, kteří finální čtení návrhu ústavy soustavně bojkotovali výkřiky a nevybíravým chováním. Přesto se podařilo prosadit některé důležité body státoprávní ${ }^{72}$ i národnostně-jazykové ${ }^{73}$. Nová československá ústava patřila be-

69 Tamtéž, hlava druhá, $\$ 8, \$ 11, \$ 13, \$ 16$. K dlouhým diskusím o vzniku druhé komory československého parlamentu nejlépe srov. Z.V. Tobolka, Jak vznikla ústava Československé republiky z roku 1920, Praha 1946, s. 15 an; synteticky uvádí v kontextu tuto diskusi také A. Klimek, Velké dèjiny zemí Koruny České, XIII., Praha - Litomyšl 2000, zejména s. 141-143.

70 Tamtéž, hlava druhá, \$58, (4): „Kdo byl presidentem po dvě po sobě jdoucí volební období, nemůže opět zvolen býti, dokud od skončení posledního období neuplyne sedm let; ustanovení toto nevztahuje se na prvního presidenta Československé republiky." Potvrzení tohoto zvláštního postavení Masaryka bylo nepřímo učiněno ještě zákonem č. 22/1930 Sb. o zásluhách T.G. Masaryka (tzv. Lex Masaryk), který je právně nenormativní a v demokratických parlamentárních (tj. neprezidentských) systémech značně neobvyklý.

71 Zákon č. 121/1920 Sb., kterým se uvozuje Ústavní listina Československé republiky, \$ 64.

72 Ty přednesl v úvodním referátu poslanec Bouček. Společná digitální česko-slovenská parlamentní knihovna, Národní shromáždění 1918-1920, Stenoprotokoly, 125. chůze, 27. II. 1920 (dostupné online: www.psp.cz).

73 Tamtéž, řeč předsedy československé vlády Tusara. Poslanec Hnídek poté konkrétně hovořil o jazykových zákonech a jejich implementaci v souvislosti s právy jazykových a národnostních menšin. 
zesporu k nejdemokratičtější ústavním listinám tehdejší Evropy. Poprvé přiznala ve svém textu jasné a nezpochybnitelné volební právo (aktivní i pasivní) všem ženám; stejně tak všem národnostním a jazykovým menšinám v Československu umožnila neomezeně vstupovat do politické činnosti a soutěže o volební hlasy. Protože volební systém první republiky pracoval s vázanými kandidátními listinami, v nichž nebylo možné preferovat některého $\mathrm{z}$ kandidátů dané strany, zavdala ústava rovněž značné možnosti k rozvoji širokého spektra československého politického stranictví.

Specifický jev československé státnosti vytvářelo po roce 1920 velmi nevyvážené postavení autonomních reprezentací jednotlivých území republiky. Formálně se do roku 1928 stát dělil do nižších územně-správních celků: země České, země Moravské, země Slezské, země Slovenské a země Podkarpatoruské74 ${ }^{74}$ Československá republika přistupovala $\mathrm{k}$ dílčím územním celkům rozdílně.

Patrné to bylo zejména v prípadě jejích východních území - Slovenska a Podkarpatské Rusi. Zatímco Slovensko nedostalo v rámci ústavy žádný lokální zákonodárný orgán či sněm, nejnovější část státu, Podkarpatská Rus ${ }^{75}$, měla zdánlivě velká privilegia. Disponovala vlastním sněmem, který byl „př́slušný usnášeti se o zákonech ve věcech jazykových, vyučovacích, náboženských, místní správy, jakož i v jiných věcech, které

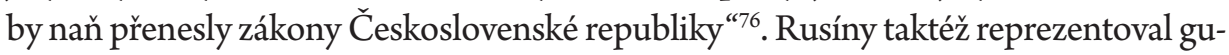
vernér Podkarpatské Rusi, jmenovaný prezidentem republiky. Slovensko žádné takové orgány neobdrželo a přes protesty některých poslanců se Slovákům podobné vymezení pro svou zemi prosadit nepodařilo. ${ }^{77}$ Autonomie Rusínů byla však jen zdánlivá. Již

74 Později došlo k administrativnímu sloučení Moravy a Slezska a vzniku země Moravskoslezské. Srov. Z. Hledíková a kol., Dějiny správy v českých zemích od počátků státu po současnost, Praha 2007, s. 351-352. Srov. dále Zákon ze dne 29. II. 1920, č. 126 Sb. ve znění zákona ze dne 14. VII. 1927, č. $125 \mathrm{Sb}$. o organisaci politické správy.

75 Toto území se stalo součástí státu až od roku 1919 na základě saint-germainské smlouvy. Srov. Smlouva mezi čelnými mocnostmi spojenými i sdruženými a Československem, podepsaná v Saint-Germain-en-Laye dne 10. IX. 1919 č. 508/1921 Sb. Smlouva formálně slíbila také dílčí autonomii pro Podkarpatskou Rus.

76 Zákon č. 121/1920 Sb., kterým se uvozuje Ústavní listina Československé republiky, \$ 2 (4).

77 Již během čtení finálního textu ústavy: Společná digitální česko-slovenská parlamentní knihovna, Národní shromáždění 1918-1920, Stenoprotokoly, 125. chůze, 27. II. 1920 (dostupné online: www.psp.cz). - První autonomní zákonodárný sbor - Sněm Slovenskej krajiny - byl ustanoven až v období druhé republiky, po uznání slovenské autonomie. Volby do sněmu proběhly 18. XII. 1938 a sněm se poprvé sešel ke složení poslaneckých slibů 18. I. 1939. Srov. Spoločná Česko-Slovenská digitálna parlamentná knižnica, Sněm Slovenskej krajiny 1, 1939, stenozáznam, 11. januára 1939 (dostupné online: www.nrsr.sk). 
ústava sama označila zákonodárnou činnost jakýchkoli zemských sněmů za zrušenou a ustavila zákony přijaté Národním shromážděním za platné pro celou republiku ${ }^{78}$. Usnesení podkarpatoruského sněmu byla pro parlament pouze doporučující, nikoli závazná. Právo veta proti zákonům Podkarpatské Rusi měl i prezident republiky ${ }^{79}$. Proto je nutné vnímat sněm Podkarpatské Rusi spíše jako formální zemskou, nikoli autonomní reprezentaci. Samotní rusínští politici si toho byli vědomi, a proto požadovali, aby autonomie nabyla reálný základ. Nicméně ani tuto iniciativu Národní shromáždění nevyslyšelo ${ }^{80}$. Československá republika zůstala do velké míry centralizovaným, unitárním státem, a byla-li kdy v průběhu Velké války nebo po ní nějaká míra autonomie přislíbena, ústavou z roku 1920 byly diskuse tohoto druhu v podstatě negovány. Československý parlament věděl, že případné vyhlášení dílčí autonomie by podnítilo žádat podobná privilegia také další národností a jazykové minority, přičemž podobné aktivity u československých Madarů a Němců by byly pro existenci samotné státnosti Československa zvláště nebezpečné.

Národní shromáždění považovalo schválenou ústavu za důležitý výsledek své činnosti a nepřipustilo její znehodnocení nebo jakékoliv rozsáhlé změny. Po úspěšném atentátu na jednoho ze zakladatelů státu, Aloise Rašína (†18. I. 1923), přijal parlament zákon na ochranu republiky, který explicitně zmínil již v prvním paragrafu, že ten, „kdo se pokusí násilím změniti ústavu republiky, zejména pokud jde o samostatnost, jednotnost nebo demokraticko-republikánskou formu státu ... trestá se těžkým žalářem “81. Svůj nesouhlas s tímto zákonem vyjádřili jednak v parlamentní diskusi komunisté, kteří soudobou podobu státu neuznávali a jejich odpor se dal předpokládat, jednak mimo zákonodárný sbor také českoslovenští Němci, kteří $\mathrm{v}$ přijetí daného zákona spatřovali nástroj pro uplatnění národnostních perzekučních postupư ${ }^{82}$. Protesty však neměly na přijetí zákona žádný větší vliv a československý stát ukázal prostřednictvím svých zákonodárců, že principy své státnosti, vtělené do konstituce, hodlá nadále dodržovat a nebude o nich diskutovat.

\footnotetext{
78 Zákon č. 121/1920 Sb., kterým se uvozuje Ústavní listina Československé republiky, \$ 7 (1), (2).

79 Tamtéž, \$ 64, (1), část 5.

80 Za zmínku zde jistě stojí také známá rezignace Hrihorije Žatkoviče (1886-1967), guvernéra Podkarpatské Rusi v letech 1920-1921, jako protest proti tomu, že přislíbená autonomie nebyla realizována.

81 Zákon 50/1923 Sb. na ochranu republiky ze dne 19. března 1923, \1.

82 Srov. dílčí vystoupení poslanců: Společná digitální česko-slovenská parlamentní knihovna, Národní shromáždění 1918-1920, Stenoprotokoly, 194. schůze, 6 III 1923 (dostupné online: www.psp.cz).
} 
Vzdor nerovnovážnému postavení jednotlivých zemí a nevyvážené situaci v existenci regionálních orgánů, silné pozici prezidenta a nesmlouvavému postoji vlády vůči požadavkům národních a jazykových minorit můžeme Československo hodnotit v letech 1918-1938 jako stát demokratický. Zejména ve třicátých letech, kdy sousední země střední Evropy soustavně obcházely či měnily vlastní zákony a ústavní zvyklosti podle svých aktuálních potřeb, zachovávala si Československá republika základní principy demokratické státnosti. Nesáhla nikdy k násilné politické přeměně vlastního uspořádání. Ani v období hospodářské krize nedošlo $\mathrm{k}$ narušení či dokonce rozbití státních principů, na nichž bylo Československo ukotveno. I když byl $\mathrm{v}$ roce 1933 přijat tzv. zákon o mimořádné moci nařizovací ${ }^{83}$, který přenesl dílčí zákonodárné pravomoci na vádu, nejednalo se o postup, který by dovoloval soustředit absolutní moc v rukou úzké skupiny českých a části slovenských politiků. Vláda sice mohla v době nejhlubší hospodářské krize zcela měnit hospodářskou politiku bez souhlasu parlamentu (např. určováním cen, celních sazebníků, monopolů atd.), ale na rozdíl od Německa, kde $\mathrm{v}$ téže době tzv. zmocňovací zákon v podstatě přetransformoval Výmarskou republiku v nacistický totalitní stát ${ }^{84}, \mathrm{v}$ Československu nedošlo k rozsáhlému zneužití mimořádných kompetencí vlády pro vytvoření jakékoli formy diktatury. Také přijaté hospodářské zákony stále vycházely z demokratického ducha republikánské ústavní listiny a byly považovány za krátkodobá opatření. Státní moc také nezasáhla proti menšinám, neomezovala jejich školská a kulturní práva, ani v průběhu sporů a krizí roku 1938 se nepokusila změnit postavení Němců, naopak byla ochotna ustoupit až na úroveň rozsáhlé kulturní i politické autonomie. Vojenský zásah proti německým ozbrojencům nebyl snahou likvidovat národnost, ale pouze bránit bezpečnost republiky a odpovídal tedy republikánské ústavě.

Konec československé státnosti přinesla až Mnichovská dohoda čtyř velmocí ze zárí 1938. Republika byla nejen nucena postoupit třetinu svého území Německu, ale došlo i ke zhroucení všeobecného konsenzu nad platností československé ústavy. Parlament byl v období druhé republiky zcela dezorientován a pod rostoucím tlakem dalších separatistů konečně přijal také zákony o autonomii Slovenska ${ }^{85}$ a Podkarpat-

83 Zákon č. 95/1933 Sb. o mimořádné moci nařizovací.

84 Gesetz zur Behebung der Not von Volk und Reich, 24 III 1933. Zejména $\$ 1-\$ 3$ zcela převedly moc vydávat všechny zákony na vládu, kancléře a prezidenta.

85 Ústavný zákon č. 299/1938 Sb. z. a n. zo dňa 22. novembra 1938, o autonomii Slovenskej krajiny. Zákon byl ve sbírce zákonů vydán ve slovenštině, aby posílil iluzi vítězství v tomto dlouhodobém snažení některých slovenských politických skupin. 
ské Rusi ${ }^{86}$. Byla to však jen labutí píseň československého zákonodárství. Ústavní listina sice zůstala oficiálně v platnosti až do okupace českých zemí v březnu 1939, ale byla soustavně obcházena a nedodržována. I samotný parlament, který měl v konstrukci státnosti Československa své nezastupitelné místo, byl vnímán jako přežitek doby, mizející v nenávratnu. Pod vlivem př́klonu politické sféry doprava zopakovala Česko-slovenská republika nacistický model a přijetím tzv. zmocňovacího zákona $\mathrm{v}$ prosinci $1938^{87}$ vyřadila parlament $\mathrm{z}$ veřejného politického života.

V době druhé světové války a okupace je třeba považovat Protektorát Čechy a Morava za loutkový stát nacistického Německa, který fungoval neústavně a nevykazoval prakticky žádné známky svébytné státnosti.

Brzy po skončení války byl v ř́ijnu 1945 parlament obnoven, i když jeho ustavení bylo pro omezené možnosti provedeno formou delegačních voleb. Oprávněně to bylo vyjádřeno názvem Prozatímní národní shromáždění. Zákonodárný sbor zvolený o rok později již v klasicky prováděných tajných volbách dostal př́zvisko ústavodárný, když mu bylo přisouzeno připravit na základě rozhodnutí politických stran spolupracujících v Národní frontě Čechů a Slováků do př́ístích parlamentních voleb novou ústavu, která bude reflektovat všechny politické, ekonomické a sociální změny v charakteru poválečného státu. Národní shromáždění si původní podobu zastupitelského sboru, v němž zvolení poslanci hájí politické zájmy samostatných stran, dlouho neudrželo, i když na jeho půdě probíhaly ostré politické šarvátky. Parlamentní půtky vliv na politiku státu neměly; povahu přijímaných zákonů určovala vláda, jednající jménem Národní fronty. Její moc, mající od počátku v osvobozeném státě ráz monopolního rozhodování, umenšila význam parlamentu. $\mathrm{K}$ dalšímu oslabení demokratického charakteru státu směřoval vliv a tlak Gottwaldova vedení komunistické strany, které se stalo rozhodujícím faktorem tohoto procesu, až na konec v únorovém převratu 1948 KSČ stát zcela ovládla a podřídila si také Národní frontu. V nových politických poměrech proběhly sice volby, ale kvůli tomu, že KSČ zavedla tzv. jednotnou kandidátku obrozené Národní fronty, ztratily charakter voleb svobodných, tajných a pluralitních. Nová ústava, přijatá Národním shromážděním

\footnotetext{
86 Ústavní zákon ze dne 22. XI. 1938 č. 328/1938 Sb. z. a n., o autonomii Podkarpatské Rusi.

87 Ústavní zákon č. 330/1938 ze dne 15. XII. 1938 o zmocnění ke změnám ústavní listiny a ústavních zákonů republiky Česko-Slovenské a o mimořádné moci nařizovací. Právo přijímat zákony přecházela na prezidenta a vládu (čl. 1 a 2).
} 
9. V. 1948, zbavila parlament ústavního postavení nejvyššího orgánu státní moci. Československý parlamentarismus fungující na této predikci po celé předválečné dvacetiletí a znovu v letech tzv. Třetí republiky tak ztratil své výsostné postavení. Do budoucna byl transformován do pozice sboru, trpně přijímacího zákony připravené vedením KSČ.

Obnova československého poválečného politického systému doznala výrazných změn. Nebylo to jen připoutání politických stran k protifašistické koalici Národní fronty, ale rovněž zavržení koncepce čechoslovakismu. Slovenský národ si Slovenským národním povstání, v němž se na konci srpna 1944 přihlásil k obnově Československa, vybojoval uznání národní svébytnosti a svéprávnosti. Národní fronta Čechů a Slováků ještě na sklonku války při jednáních o svém vládním programu poválečné obnovy vyhlásila postavení obou národů za rovnoprávné. Princip federálního uspořádání sice slovenská politická reprezentace neprosadila, ale základní teze Košického vládního programu porušeny nebyly, i když v poválečném politickém střetávání byly postupně třemi pražskými dohodami z let 1945-1946 likvidovány pravomoci slovenského Sboru pověřenců jako představitele výkonné moci slovenské autonomie. Slovenská národní rada a Sbor pověřenců zůstaly zachovány i podle nové lidově demokratické ústavy. Až v dalším vývoji komunistického státu se vedle ztracené parlamentní demokracie a oslabeného postavení celostátní zákonodárné moci objevilo další oslabování slovenské autonomie. K řešení složitě se vyvíjejícího česko-slovenského státoprávního uspořádání a stejně tak k obnově nejvyšší pozice Národního shromáždění v soustavě státní moci přispěla až šedesátá léta.

\section{II.}

Do historie československého parlamentarismu za poválečného komunistického období přinesla výrazný zásah ústava z roku 1960. Ústava byla silně ideologicky podbarvena a podle historiků práva právní kulturu oslabila. Odrazilo se to v jejím celkovém pojetí, obsahu i koncepci jednotlivých ustanovení. Je považována především za politický dokument, který odrážel z právního hlediska politickou realitu přesněji než Ústava 9 . května ${ }^{88}$.

88 V. Pavlíček a kol., Ústavní právo a státověda II. Ústavní právo České republiky, Praha 2011, s. 235-249. Část textu V. Bauerové zveřejněna též na https://www.ustavprava.cz/blog/2018/04/ socialisticka-ustava/. 
Ústava 9. května byla Národním shromážděním schválena právě v den třetího výročí osvobození Československa a odtud získala své pojmenování ${ }^{89}$. Prezident republiky dr. Edvard Beneš ji sice odmítl podepsat, ale o měsíc později v červnu 1948 to učinil po své volbě prezidentem předseda KSČ Klement Gottwald. Ústava byla přijata sice až po ovládnutí státu komunisty, ale stalo se tak v samých počátcích rodící se diktatury ${ }^{90}$. $V$ ústavě, připravované ještě v Ústavodárném národním shromáždění, zůstala proto ponechána ustanovení o občanských právech, která byla doplněna katalogem práv sociální povahy a stanovením základních povinností občana ke státu, což lze chápat jako jisté omezení ${ }^{91}$. Dikce ústavy ještě hranice parlamentní demokracie neopustila. $V$ následujících týdnech a měsících vyústila totální přeměna stranické struktury v monopol vítězné KSČ. Realita třídně definovaného státu (diktatura proletariátu podle marxisticko-leninských pouček), orientovaného ostře proti soukromému podnikání, a z toho vyplývající povaha společenských vztahů potom

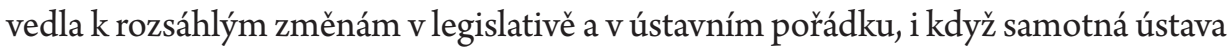
zůstala nezměněna. Nejprve došlo k oslabení občanských práv a nakonec $\mathrm{v}$ praxi k úplnému popření svobody vyjadřování, shromažd'ování a sdružování.

Ústava rovněž umenšila význam Národního shromáždění v soustavě orgánů státní moci. Zákonodárný sbor se musel smířit se ztrátou pozice nejvyššího orgánu státní moci a spokojit s omezením své vrcholové pozice na oblast zákonodárné moci. Ale ani postavení nejvyššího orgánu zákonodárné moci do budoucna nezaručovalo ${ }^{92}$, že v této úrovni bude jeho funkce reálně respektována. Parlament neměl fakticky žádné zásadní pravomoci. $V$ podstatě se $\mathrm{z}$ něho stal sbor, který pouze odhlasovával zákony připravované vládou a předem projednané na ÚV KSČ. Činil tak však svědomitě 93 .

V tomto uspořádání se nic nezměnilo ani po roce 1960, ústava dokonce skutečnosti z fungování mocenských mechanismů komunistického režimu pojala za svůj základní princip. Na jedné straně vrátila socialistická ústava parlament do pozice vrcholné státní moci, když shromáždění prohlásila jejím nejvyšším orgánem ${ }^{94}$, na

\footnotetext{
89 Ústavní zákon ze dne 9. V. 1948, č. 150/1948 Sb.

90 K. Kaplan, Poslední rok prezidenta. Edvard Beneš v roce 1948. Praha 1993, s. 57 an.

91 Ústavní zákon č. 150/1948 Sb., kap. I, čl. 1-38.

92 Tamtéž, čl. V. V II. kapitole, č 39-66 je rozvedena řada ustavení k fungování parlamentu, povinnostem poslanců a pravomocím předsednictva NS.

93 K. Kaplan, Kořeny, s. 205.

94 Ústavní zákon ze dne 11. VII. 1960, č. 100/1960 Sb., čl. 39, odst. 1.
} 
druhé straně byla v jejím textu zahrnuta teze o vedoucí úloze KSČ ve státě ${ }^{5}$. Vyhlášení parlamentu za vrcholný státní orgán bylo totiž opět pouhou formální deklarací vrcholového postavení. Pozitivní posun v redefinování ústavního postavení neměl žádný dosah na změnu dosavadní praxe, $v$ níž zůstávaly zaběhané mechanismy politického rozhodování nezměněné. Skutečnému naplnění ústavy v rovině parlamentních pravomocí bránil politický monopol KSČ, který nadřazoval stranické orgány nad orgány státní moci v celé struktuře státní administrativy i zastupitelské soustavy.

Skutečnost, že ústava z léta 1960 dokonce uzákonila vedoucí úlohu monopolně vládnoucí politické organizace KSČ, znamenala, že její vưdčí politická moc se stala trvalým atributem ústavního práva byrokraticko-centralistického státu sovětského typu. Reálně tak totálně zhmotnila politický monopol jako součást ústavního uspořádání, učinila jej nezpochybnitelným.

Liberalizační snahy, k nimž vedení KSČ přistoupilo pod tlakem vývoje po roce 1963, se po volbách nového parlamentu a Slovenské národní rady v červnu 1964 promítly i v postoji vedení KSČ vůči parlamentu. Rozpor mezi ústavou deklarovanou pozicí a jeho reálným vlivem byl př́iliš velký, navíc celková společenská nálada byla odlišná od poměrů sklonku padesátých let, očekávání změn bylo všudypřítomné, zvláště když se hovořilo o rozvoji socialistické demokracie, dělbě moci při řízení společnosti a všelidovém státě. Přijetí rezoluce ÚV KSČ o zlepšení práce a postavení parlamentu v květnu 1964 se velmi rychle začalo promítat do praxe nově zvoleného Národního shromážděni ${ }^{96}$. Jeho vedení na čele s Bohuslavem Laštovičkou se výrazně angažovalo v naplňování nové stranické směrnice, zvláště když ohlašovala posílení pravomoci zákonodárných orgánů a prohloubení jejich účasti na rozvíjení tzv. socialistické demokracie. Národní shromáždění bylo orientováno ke zlepšení zákonodárné činnosti zvýšením účasti sboru na tvorbě zákonů, na posílení jeho autority v rámci zastupitelské soustavy, k navázání hlubší spolupráce se Slovenskou národní radou jakožto zákonodárným reprezentantem slovenské autonomie a na zlepšení jeho kontrolní úlohy vůči orgánům výkonné moci, zejména resortním ministerstvům. V uvedených směrech se dokonce dařilo v určité míre naplňovat zadání a prohlubo-

95 Vedoucí úlohu komunistické strany deklaroval 4. čl. ústavy slovy: „Vedoucí silou ve společnosti i ve státě je bojový předvoj dělnické třídy, Komunistická strana Československa, bojový svazek nejaktivnějších a nejuvědomělejších občanů z řad dělníků, rolníků a inteligence“. Dosavadní stav vlády KSČ nad státem byl de iure vtělen do ústavy.

96 Usnesení PÚV KSČ o prohloubení činnosti Národního shromáždění byla otištěna v Rudém právu, tiskovém orgánu ÚV KSČ a v dalších několika novinách. Srov. Rudé právo, 20. V. 1964, č. 139, s. 1-2. Více k tomu O. Felcman, Československý parlament, s. 43 an. 
vat pozici Národního shromáždění v zastupitelské soustavě tvořené od roku 1949 národními výbory krajskými, okresními a místními, ale i vưči $\mathrm{SNR}^{97}$. Nadřízené postavení celostátního zákonodárného sboru nad slovenským „parlamentem“ bylo mírněno zdůrazňováním potřeby úzké spolupráce obou zastupitelských orgánů, de facto v letech 1964-1967 naplňovanou i zvolením předsedy SRN Michala Chudíka za jednoho z místopředsedů Národního shromáždění. Lze souhlasit s K. Kaplanem, že v letech 1966-1967 se Národní shromáždění vymanilo z dosavadní bezvýznamnosti ${ }^{98}$, ke klíčovému zápasu o pozici parlamentu v politickém systému odpovídající dikci ústavy však ještě doba nedospěla.

Ústava přijatá jako jeden z článků dokladujících dosažení základních hodnot socialistického uspořádání společnosti přinesla kromě uváděných změn ještě jednu negativní proměnu, a sice oslabení slovenské autonomie. Zatímco Ústava 9. května ústavně posvětila existenci SNR a Sboru pověrenců a přinesla tak oproti prvorepublikánské ústavě zásadní změnu do podoby česko-slovenských vztahư ${ }^{99}$, ústava z roku 1960 slovenský národ a specifické postavení Slovenska ve státě poškodila. Ze Slovenské národní rady vytvořila národní orgán státní moci a správy s hybridním vymezením kompetencí sahajícím od schvalování zákonů národní nebo regionální povahy k účasti na plánování, schvalování rozpočtu a kontrole ve své působnosti ${ }^{100}$. Především zrušila Sbor pověřenců, představující regionální slovenskou vládu, resp. výkonný orgán Slovenské národní rady, sice úzce provázaný s ústředními orgány státní správy - ministerstvy, ale doposud stále samostatný orgán ${ }^{101}$.

Kompetence sboru pověřenců byly převedeny na předsednictvo SNP, tedy do pravomoci kolektivního orgánu stojícího včele slovenského zákonodárného sboru, který dostal pravomoci výkonného orgánu. Míra slovenské autonomie byla tak výrazně umenšena. Předsednictvo SNR sice ze svého středu volilo pověřence SNR, ale jejich působnost byla vymezena rámcově jako plnění svěřených úkolů v mezích pravomoci SNR, přičemž SNR mohla svého pověřence kdykoliv odvolat ${ }^{102}$. Vytvořil se tak zvláštní ústavně právní vztah, když zákonodárný orgán měl sám některými

97 K proměnám parlamentní činnosti tamtéž, 2. kapitola, s. 43-75. Dále též K. Kaplan, Kořeny, s. 206-208.

98 Tamtéž, s. 209.

99 Přehledně pojednává o vývoji česko-slovenského vztahu K. Kaplan, Pravda o Československu, s. 159-192.

100 Ústavní zákon č. 100/1960 Sb., čl. 73 a 74.

101 VI. hlava ústavy pojednává v čl. 73-85 jen o SNR, jejím předsednictvu a komisích.

102 Tamtéž, čl. 85, odst. 1 a 3. 
svými členy a komisemi zajištovat část výkonné moci. A bez ohledu na to, že byl považován za národní orgán, byl plně začleněn do centralistické soustavy celostátního ř́zení ${ }^{103}$. K dovršení všeho se vedení KSČ podařilo, že odůvodnění změn vedoucích k oslabení slovenské autonomie předkládala tehdejší slovenská politická reprezentace $\mathrm{s}$ argumentem, že jde o posílení práv slovenských orgánư ${ }^{104}$.

Po počátečním souhlasu slovenské politické reprezentace se brzy začal - také v souvislosti s prováděnými dílčími rehabilitacemi komunistických funkcionářů postižených ve stalinistických politických procesech - postoj slovenské veřejnosti měnit. Obzvláště citlivým tématem byl tzv. slovenský buržoazní nacionalismus, kvưli kterému byli počátkem padesátých let neoprávněně zatčeni přední funkcionáři SNR na čele s Gustávem Husákem a později odsouzeni k dlouholetému vězení ${ }^{105}$. Vzniklé napětí v československých vztazích se centralistické komunistické vedení státu pokusilo snížit a rostoucí odpor slovenských činitelů eliminovat. V roce 1963 byly několika zákony a vládními nařízeními provedeny dílčí úpravy, avšak nedostačovaly. Trvající nespokojenost a pocit bezmocnosti SNR nakonec vyústily v rozsáhlejší úpravy, posílení pozice SNR, zvýšení počtu pověřenců, přejmenování odborů

103 K tomu K. Kaplan, Kořeny, s. 234-246; též v hutné zkratce Z. Jičínský, Vznik české národní rady, s. 11 .

104 K. Kaplan, Kořeny, s. 240 a 245. K širším příčinám a souvislostem omezování slovenských autonomních institucí srov. M. Londák, S. Sikora - E. Londáková, Predjarie, Bratislava 2002.

105 JUDr. Gustáv Husák (1913-1991), slovenský komunista, jeden z vůdců Slovenského národního povstání, po válce předseda Sboru pověřenců. V únoru 1948 podřídil slovenskou politiku definitivně KSS a likvidoval jejího největšího protivníka Demokratickou stranu. V roce 1950 byl zbaven funkce předsedy Sboru pověřenců a o rok později zatčen. Přes dlouhotrvající fyzický i psychický nátlak se k protistátní činnost nepřiznal. V dubnu 1954 byl odsouzen Národním soudem v Bratislavě k doživotnímu žaláři, v červenci 1960 amnestován, v roce 1963 občansky i stranicky rehabilitován. Ve Slovenské akademii věd obhájil na základě rozsáhlé monografie Svědectví o SNP titul kandidáta právních věd (CSc.) a v polovině 60. let se stal uznávaným a obdivovaným představitelem slovenské intelektuální levice, ostře stojící proti pražskému centralismu a podporující provedení reforem. Po lednu 1968 se za Pražského jara stal místopředsedou vlády ČSSR zodpovědným za provedení federalizace. Po okupaci na konci srpna 1968 patřil k prvním realistům, politikům, kteří se rozhodli respektovat sovětskou mocenskou převahu a podřídit se jí. U Sovětů si získal důvěru, když jako nově zvolený první tajemník ÚV KSS dokázal rychle normalizovat Slovensko. V dubnu 1969 byl zvolen místo Alexandra Dubčeka prvním tajemníkem ÚV KSČ, poté zahájil ostré tažení proti slábnoucímu reformnímu křídlu. Rozsáhlou výměnou stranických a státních funkcionářu a stranickou čistkou v roce 1970 stabilizoval normalizační režim, jehož neměnnost zajištoval na čele KSČ až do prosince 1987. I potom zůstal až do pádu komunistické moci na konci roku 1989 prezidentem republiky; abdikoval 10. prosince. Srov. podrobně k jeho životu a činnosti M. Macháček, Gustáv Husák, Praha 2017. 
SNR na pověřenectva, apod. Posuny v kompetencích slovenských národních orgánů oznámil dokument Za plnější uplatnění SNR, přijatý společným zasedáním ÚV KSČ a ÚV KSS 7. V. $1964^{106}$.

Nápravy z let 1964-1966 měly nedostatečný rozsah, Sbor poveřenců nebyl obnoven. Nebyly odstraněny ani všechny důsledky nesprávného ústavního kroku z roku 1960. Přes snahu zohlednit společensko-politický vývoj na Slovensku v polovině šedesátých let byly nastalé změny jen nicotným posunem a nikoliv reálným krokem mírícím k uznání oprávněnosti slovenských státoprávních snah. Hranice asymetrického uspořádání byla nepřekročitelná, $\mathrm{v}$ pozadí stála obava z ohrožení jednoty státu ${ }^{107}$.

Pro objektivitu je třeba konstatovat, že vlastní státnost neměl v rámci společného státu ani český národ. Pokus o její institucionální zformování, jak jej od sklonku války představovala Česká národní rada (ČNR), byl bezprostředně po osvobození země na nátlak Moskvy československou vládou odmítnut ${ }^{108}$. Bylo zjevné, že v poměrech nastolených a udržovaných komunistickým systémem nebylo možné najít důstojné státoprávní řešení, které by přiznalo právo na vlastní státnost dvěma nestejně velkým bratrským národům a přitom neznamenalo rozpad společného státu. Nebyl to jenom čechoslovakismus, který ve vedení KSČ přetrvával, ale i obava z oslabení moci pražského centralismu. I dvacet let po osvobození stál v cestě snahám o vytvoření takového vnitrostátního uspořádání, které by bylo spravedlivé vůči oběma národům. V roce 1967 se však poměry dále vyostřily, v česko-slovenském vztahu přerostlo latentní napětí $\mathrm{v}$ otevřenou krizi, kterou prezident Novotný svými neuváženými činy dále prohluboval. Krizově působilo i jeho rozhodnutí zastavit demokratizační trendy a znovu v plné míre obnovit kontrolu stranického vedení nad společností.

106 Dokument byl publikován až s odstupem. Rudé právo, 22. V. 1964, č. 141, s. 2. Více o těchto změnách K. Kaplan, Kořeny, s. 246-255. K novému pojetí vztahu mezi parlamentem a SNR srov. O. Felcman, Československý parlament, s. 56-58.

107 K. Kaplan, Kořeny, zejména, s. 250-251.

108 ČNR vznikala od léta 1944 v několika etapách jako koordinační orgán protifašistického hnutí českého lidu, který se měl stát po válce nový orgánem moci v českých zemích. Na konci dubna 1945 se zformovala do konečné podoby, postavila se za program košické vlády Národní fronty a stanula v čele Květnového povstání českého lidu. Svou činnost oficiálně ukončila 12 . V. 1945. Stručně např. Český antifašismus a odboj. Slovníková př́ručka, Praha 1988, s. 50-51. Nejnověji k okolnostem kolem ČNR a jejím zániku srov. D. Tomášek, Vláda emigrantů. Duben - listopad 1945, Praha 2009, s. 11-23. 
Politicko-společenská a vnitrostranická krize dospěla na konci roku 1967 k vrcholu. Její řešení nakonec přineslo zasedání ÚV KSČ, které začalo v prosinci 1967 a po přerušení kvůli vánočním svátkům pokračovalo 3.-5. I. 1968. V závěru pléna odstoupil nejvyšší představitel KSČ Antonín Novotný z funkce prvního tajemníka ÚV KSČ a na jeho místo byl zvolen dosavadní první tajemník ÚV KSS Alexander Dubček ${ }^{109}$. Nejhorší fáze politické krize byla ukončena. Československu a KSČ se otevřela cesta k potřebným změnám, i když na jejich vymezení a konkretizaci bylo třeba vynaložit hodně námahy, aby byla krize zcela překonána.

Úvahy a představy o potřebných reformách se objevily v druhé polovině ledna a postupně nabíraly na četnosti a intenzitě; sílící odvaha přinášela stále zřetelnější návrhy na řešení dlouholetých společenských problémů. Ve hře bylo odstranění byrokraticko-centralistického systému sovětského typu. Nové vedení KSČ nehodlalo nadále pokračovat v totální kontrole společnosti, naopak se klonilo k výrazné demokratizaci společenského uspořádání, což mohlo mít pozitivní dopad na politické poměry a podobu státnosti. Na Slovensku dostávalo silnou veřejnou rezonanci úsilí po novém státoprávním uspořádání státu, diskuse o nezbytnosti zásadní změny $\mathrm{v}$ postavení slovenského národa ve společném státě Čechů a Slováků nabývala na stále širším rozsahu.

S nevelkým časovým odstupem se mezi českými právníky začalo diskutovat o úpravách československé legislativy a vhodnosti př́pravy nové ústavy, což nevy-

109 Antonín Novotný (1904-1975), český komunistický politik a československý státní činitel, stojící v čele KSČ od zárí 1953 do ledna 1968 a v čele státu jako prezident republiky od listopadu 1957 do března 1968. Nástupce Klementa Gottwalda, byl politicky spoluzodpovědný za politické procesy a nesl hlavní zodpovědnost za oddalování jejich revize a rehabilitace nespravedlivě odsouzených komunistů i nestraníků. Jako představitel politiky konzervativní destalinizace se výrazně zasloužil o hlubokou krizi v KSČ a společnosti na sklonku 60. let. I po vzdání se funkce prvního tajemníka ÚV KSČ zůstával členem nejvyšších stranických orgánů a velmi brzy začal vystupovat proti reformním snahám. O Novotném např. J. Pernes, Takoví nám vládli: Komunističtí prezidenti Československa a doba, v níž žili, Praha 2010, zejména s. 163-269. Alexander Dubček (1922-1991), slovenský a československý komunistický politik, výrazně spjatý s proreformní politickou prací období Pražského jara. V letech 1963-1968 první tajemník ÚV KSS, od 5. I. 1968 do 17. IV. 1969 první tajemník ÚV KSČ. Poté do záŕí 1969 předseda Federálního shromáždění ČSSR, kdy byl odvolán ze všech politických funkcí a později vyloučen z KSČ. Ve dnech invaze byl zajat a několik dní zadržován sovětskou tajnou službou. 
lučovali ani politici ${ }^{110}$, a o posílení občanských práv, k nimž výrazně přispělo faktické zrušení cenzury na počátku března 1968. S obnovou informační svobody se začala oživovat občanská společnost, odrazem toho bylo neomezované využití shromažd'ovacího a sdružovacího práva. Vedle nesčetných shromáždění, na nichž se otevřeně diskutovaly politické otázky, a vedle obnovy a vzniku různých organizací a spolků se proměňovaly politické strany a společenské organizace. Polednový reformní proces, označený novináři za pražské jaro, skutečně začal.

Mechanismus převodových pák, jehož prostřednictvím si KSČ zajištovala politický monopol, se vytratil takřka ze dne na den. Jen o něco pomaleji se začaly rodit úvahy o nové koncepci vnitřního uspořádání Národní fronty postavené na proměně vztahů mezi KSČ a ostatními politickými stranami. K oteplení ve společnosti přispělo otevření hranic a povolení možnosti cestovat stejně jako výrazná změna postoje státu k církvím a náboženským organizacím. Výsledkem tohoto trendu bylo obnovení řeckokatolické církve. Mnohé z těchto změn obsahoval Akční program KSČ, který byl sice rychle připraven, ale otevřeně projevená nespokojenost sovětského vedení s jeho tezemi a rychlý rozmach celospolečenské aktivity způsobily, že byl přijat zasedáním ÚV KSČ až 5. IV. 1968. Jednalo se o program demokratického socialismu, i když pozdržení jeho přijetí znamenalo, že některé z jeho záměrů byly již společenskopolitickou realitou jara 1968 překonány ${ }^{111}$.

110 Požadavek na provedení legislativních změn československého právního řádu podnítilo kolegium věd o státu a právu ČSAV a SAV a Právnická fakulta Karlovy univerzity v Praze. Na jejich základě vznikl seznam zákonů, jejichž úpravy by přicházely v úvahu. Projednal jej ústavně právní výbor NS 14. V. 1968 a po dopracování byl předložen předsednictvu NS, které o něm jednalo 13. VI. 1968. Tak se rodila jednak prognóza změn čs. právního rádu, jednak byla podnícena úvaha o potřebě zahájit práce na př́ípravě nové ústavy, která by výrazněji respektovala ústavní tradici republiky a byla založena na právních a nikoliv na politickoideologických principech. Předsednictvo NS následně rozhodlo předložit plénu parlamentu návrh na vytvoření komise, která zahájila přípravné práce pro vznik nové ústavy. Srov. F. Cigánek, O. Felcman (vyd.), Národní shromáždèní. 3/1, dok. č. 44-45, s. 233-245.

111 Československá reforma let 1968-1969 představovala nejrozsáhlejš́i a nejvíce radikální pokus o přeměnu sovětského typu socialismu na socialismus demokratický. Jeho možný rozvoj byl však závislý na vývoji mezinárodně politické situace, zejména postojů zemí východního sovětského bloku. Názory představitelů komunistických a dělnických stran a především Brežněvova sovětského vedení na československé události se rychle vyvíjely od počáteční nedůvěry přes nespokojenost až k otevřenému odporu, jehož vyústěním byla invaze pěti zemí Varšavské smlouvy před půlnocí 20. VIII. 1968 pod krycím jménem Operace Dunaj.Jejím důsledkem bylo zastavení nadějného vývoje a návrat $k$ rigidní kontrole komunistické strany nad společností. - Polednový obrodný proces, srpnová okupace spojenci a následné udušení reforem je předmětem rozsáhlé pozornosti historiků, politologů a právníků v nástupnických zemích bývalého Československa 
V politické praxi začalo výrazně působit odhodlání reformních poslanců Národního shromáždění prosadit naplnění článku ústavy o vrcholovém postavení parlamentu ve struktuře státní moci a obnovit jeho pozice vůči vládě a prezidentovi. Skutečnost, že se od března 1968 vedení parlamentu silně aktivizovalo, aby naplnilo své ústavní postavení, mohlo mít pro povahu státnosti stejně důležitý význam jako přeměna unitárního státu ve federaci. Březnová porada předsednictva NS s vládou naznačovala, že nejvyšší orgán státní moci již nebude poklonkovat vládě, ale byla i prŕslibem pro budoucno. Nové vzájemné vztahy měly být založeny na kooperaci a současně na uznání kontrolní funkce pléna parlamentu vưči vládě dané ústavou ${ }^{112}$. Stejně tak se začínal proměňovat vztah mezi zákonodárným sborem a vedením komunistické strany a jejím aparátem; nadřazenost zmizela a přímé řízení předsednictva parlamentu z př́slušného oddělením ÚV KSČ přestalo. Nelze dále přehlédnout, že to bylo Národní shromáždění, které vyzvalo v březnu 1968 prezidenta Antonína Novotného k rezignaci na ústavní funkci po té, co takový požadavek zazněl na jednání průmyslového výboru 20. III. 1968. Prezident Novotný vzápětí 22. března ze svého úřadu rezignoval ${ }^{113}$. Narůstající politický vliv parlamentu přesáhl $v$ tomto prípadě dikci ústavy, nebot' v ní byla zodpovědnost prezidenta vůči zákonodárnému sboru stanovena velmi povšechně ${ }^{114}$. O možnosti odvolání nebo přinucení prezidenta k demisi se totiž ústava nezmiňovala. Parlamentní sbor si vymohl také zvolení nového početně silnějšího předsednictva se zvýrazněným zastoupením nekomunistických politických stran a obnovu branně bezpečnostního výboru, který byl zrušen v roce 1952 a který neváhal uplatňovat svá kontrolní práva zvaním náměstků ministerstev obrany a vnitra na svá zasedání. O aktivní a politicky vlivnější roli Národního shromáždění v demokratizující se společnosti mnohé vypovídalo energické zapojení parlamentních výborů do legislativní tvorby, výrazně patrné v př́ípadě zákona o rehabilitacích politicky postižených osob.

i v cizině. Nelze ho proto historiograficky popisovat, ostatně to není ani cílem studie. Pro základní orientaci odkazujeme na práci V. Kural - V. Mencl a kol., Československo roku 1968, díl I-II. Praha 1993 a na publikaci kolektivu autorů vedeného J. Kocianem, Slovníková príručka k československým dějinám 1948-1989 (2006), zpřístupněné na webových stránkách ÚSD AV ČR, v. v. i. Praha.

112 O jednání vedení Národního shromáždění se zástupci vlády více O. Felcman, Československý parlament, s. 189-193.

113 Více k tomu např. tamtéž, s. 202-211; dále idem, Národní shromáždèní a jeho podíl v odstoupení prezidenta za Pražského jara, [in:] Systemy reprezentacji i parlamentaryzm $w$ Ewropie Środkowej w rozwoju historycznym, Katowice-Zabrze 2016, s. 296-301.

114 Ústavní zákon č. 100/1960 Sb., čl. 43 a čl. 61. odst. 2. 
Ačkoliv nespokojenost Slováků s podobou státního uspořádání na sklonku šedesátých let výrazně narostla a přispěla i k odchodu Antonína Novotného, v prvních představách o reformních plánech a cílech otázka konečného dořešení státoprávního uspořádání odstraněním asymetrie a nastolením federativní úpravy výrazně nevystupovala. Při prrípravě Akčního programu KSČ uvažovalo nové vedení KSČ o cestě $\mathrm{k}$ federaci spíše jako o postupném procesu, který bude dosahován po etapách ${ }^{115}$, i když v čele strany stál poprvé od jejího vzniku i od komunistického převratu v roce 1948 politik slovenské národnosti. Dokladem toho byla Dubčekova podpora rychlé nápravě nesprávného rozhodnutí z konce roku 1967, kdy Národní shromáždění odmítlo na základě politických tlaků přiznat Bratislavě statut hlavního města Slovenska. A tak ještě na konci února 1968 byl ve zkráceném jednání přijat parlamentem zákon, který Bratislavě př́slušný statut potvrdil ${ }^{116}$. Byl to dílčí krok, který odstraňoval křiv$\mathrm{du}$, nemohl však sloužit jako prostředek celkové nápravy.

Slovenské veřejné mínění vnímalo potřebu federalizace jako okamžitý cíl, jehož naplnění je klíčovou otázkou demokratizace. Není divu, že jako první vystoupila v polovině března $1968 \mathrm{~s}$ požadavkem federalizace státu Slovenská národní rada. Nepochybnou roli v tom sehrála diskuse slovenských a českých odborníků na vědecké konferenci ve Smolenicích na počátku března, svolaná právě k otázkám politického systému a jeho nutných proměn ${ }^{117}$. Obecně lze rríci, že oběma stranám bylo žrejmé, že uspořádání československé státnosti se musí rozejít s rezidui čechoslovakismu, $s$ paternalistickou politikou pražského centralismu, $s$ doposud poměrně častou argumentací o splývání národů i s politickou praxí, v níž vedení KSČ dlouhodobě oscilovalo mezi centralizací a decentralizací.

Znamenalo to řešit národně politické vztahy na principech skutečné rovnoprávnosti a dobudování státnosti postavit na federativních principech. Jenom federativní uspořádání společného státu mohlo zajistit oběma národům jejich dílčí suverenitu, potvrdit jejich svébytnost a vzájemně respektovanou rovnoprávnost. Avšak jeho naplnění ve smyslu skutečné občanské rovnosti př́slušníků obou národů i národnostních menšin žijících ve státě bylo podmíněno demokratizačním procesem, jehož zacílení mělo v českých zemích a na Slovensku odlišné akcenty. Existovaly v náhledu na poměr mezi procesem demokratizace upřednostňovaným v českých zemích

115 V první fázi prrípravy podkladů pro rodící se akční program strany se dokonce návrh na změnu státoprávního uspořádání vůbec neobjevil. Srov. Z. Jičínský, Vznik ČNR, s. 12 a 14.

116 O. Felcman, Československý parlament, s. 140-144.

117 Z. Jičínský, Vznik ČNR, s. 12-13. 
a federalizací, vnímanou Slováky jako klíčový prvek celkové demokratizace. Současně se projevovaly i rozdíly ve vnímání podoby federace ${ }^{118}$. Navíc se - vzhledem $\mathrm{k}$ předchozím zkušenostem vcelku pochopitelně - projevovala na slovenské straně zvýšená nacionální citlivost a obava, aby si česká strana jako větší a silnější partner neprosadila své řešení; ostatně čeští odborníci, byt' se začali státoprávními otázkami zabývat později, připravili dokonce dvě varianty ${ }^{119}$.

Návrh SNR zdůraznil národní státnost a s ní spojený národně politický princip, podle něhož měla centrální moc zajištovat pouze omezené státní funkce, těžiště moci mělo zůstat $\mathrm{v}$ národních republikách. První česká koncepce počítala s udržením společného státu a respektem k jeho vnitřní provázanosti, koncept federalizace současně spojovala s ekonomickou reformou a reformou administrativního usporádání státu. Počítala se silnějším postavením federace a s propojením národně politického principu s demokratickým principem občanské rovnosti. Druhý český návrh se blížil konfederativnímu pojetí a od počátku nevyhovoval, ale přes jisté odtržení od reality přispěl $k$ důkladnějším debatám a ke zpřesnění formulací o národně politických zájmech $^{120}$.

České prostředí se s oprávněným požadavkem federalizace státu sžívalo postupně - Akční program KSČ vytyčil požadavek jako důležitý cíl reformy, i když v delším horizontu. Když se zhruba týden po svém nástupu začala o státoprávní problémy zajímat nová vláda, dostaly obrysy řešení konkrétní tvar. Pro přípravu federalizace státu byly vytvořeny 15. V. 1968 vládní výbor pro federalizaci a odborná komise pro př́pravu návrhu ústavního zákona. Jejího vedení se ujal místopředseda vlády Gustáv Husák s posláním zajistit provedení federalizace státu ${ }^{121}$.

118 K rozdílným představám o cílech a podobě federace existuje dnes již rozsáhlá literatura historická i právní a nelze ji ani v krátkosti představit. Pro základní orientaci v zápase o federaci je nutné zmínit edici připravenou slovenským historikem J. Žatkuliakem a její historický úvod. Srov. J. Žatkuliak (vyd.), Federalizácia 5/1, s. 7-18. Srov. též Z. Jičínský, Vznik ČNR, s. 11-21. Některé z dalších souvislostí jsou vzpomínány v publikaci M. Londák, S. Sikora, E. Londáková, Od predjaria k normalizácii, Bratislava 2016.

119 Tamtéž, s. 15.

120 Autory první koncepce byli právní odborníci Jiří Grospič a Zdeněk Jičínský, autorem druhé J. Boguszak. Jejich koncepce otiskuje J. Žatkuliak, Federalizácia, zejm. dok. č. 6, 13, 14 a 19, s. 43-49, 95-111 a 131-136.

121 O. Felcman a kol. (vyd.): Vláda a prezident, ediční řada Prameny k dějinám československé krize v letech 1967-1970, 8. díl, 1. svazek: Období pražského jara (prosinec 1967 - srpen 1968), Praha-Brno 2000, dok. č. 52, s. 241. 
Vládní komise byla klíčovým místem, kde se fakticky poměřovaly česká a slovenská koncepce. V intenzivních a dlouhých jednáních komise byla diskutována široká paleta aspektů souvisejících s pojetím federativního uspořádání republiky. Důkladné zmapování obsahu diskusí by přesahovalo rámec studie, ale je možné zachytit jejich zásadní obsah, který formoval podobu připravovaného zákona i pozdější koncepce podoby federace. Diskuse, mající často povahu ostrých názorových střetů, oscilovaly kolem dvou zásadních otázek.

První bylo pojetí federace, kde bylo zjevné, že dosavadní vývoj předurčil nutnost zajistit slovenskému národu skutečně rovnoprávné postavení, a postavit proto federaci na národním principu. Obtíže působilo přesvědčení slovenských zástupců, že diskuse se má vést především na koncepci SNR, zatímco české stanovisko nebylo považováno za rovnocenné. Čeští členové, kteří chápali obavy slovenských kolegů, neodmítali princip národně politického uspořádání, ale upozorňovali, že jeho dominace by silně oslabila po léta utvářenou integritu státu a činnost federálním orgánům komplikovala. Bylo stále více patrné, že české reprezentaci chybí český politický orgán, který by vytvářel ideovou koncepci a tak jí usnadňoval zaujímání rozvážných stanovisek k národnímu principu. Vše navíc umocňovala atmosféra ve veřejnosti, zejména na Slovensku, podněcovaná v záležitosti připravované federace k radikálním postojům. Naopak zájem veřejnosti v českých zemích upřednostňoval v rámci progresivních změn politická demokratizační opatření, přičemž na jižní Moravě se rozrůstalo hnutí za trojčlennou federaci, postavenou na územně historickém principu.

Druhým řešeným aspektem byla míra kompetencí federálních a národních orgánů a podob záruk, jakými bude možné zabránit možné majorizaci požadavků silnějšího partnera, nap̌r. principem parity ve složení orgánů. Základní rozdíl mezi oběma koncepcemi spočíval v představě o rozsahu federálních kompetencí; slovenská počítala s výraznou samostatností národních orgánů, česká vycházela z přesvědčení, že federální ústředí musí mít dostatek pravomocí pro řízení věcí společného zájmu, nap̌r. další provádění ekonomické reformy. Českým zástupcům se přitom jevila v porovnání s názorovou pozicí slovenských členů, zaštitovanou SNR - jako nevýhoda absence českého národně politického orgánu. Čeští zástupci si uvědomovali nedostatečnost svého postavení; ačkoliv $k$ tomu neměli politické oprávnění, museli za neexistující českou národní reprezentaci doslova zaskakovat. $Z$ daného stavu věcí potom přirozeně musel vyplynout požadavek ustanovit takový orgán v podobě České národní rady a zakotvit jeho konstituování do připravovaného ústavního zákona.

$\mathrm{V}$ závěrečné fázi př́pravy zákona se zapojil také parlament a účinně přispěl $\mathrm{k}$ nalezení vhodné formy federativního usporádání a ustavení institucionální podoby 
národní politické reprezentace. Přijetím ústavního zákona č. 77/1968 Sb. o přípravě federativního usporádání ČSSR byl splněn vládní úkol připravit cestu $\mathrm{k}$ federalizaci země. Klíčové bylo, že pro napravení vzájemných vztahů Čechů a Slováků v rámci reformy byrokratického socialismu měla být vedle vyhlášení federace dotvořena i česká státnost. Její konstituování bylo dokonce podmínkou pro ustavení federace, protože podoba budoucí federace nemohla být naprojektována z centra. $\mathrm{O}$ ní musely rozhodovat národní politické reprezentace, a nikoliv odborná česko-slovenská jednání. Rozhodovat znamenalo, že si budou obě reprezentace předkládat návrhy, jak federativní stát pojmout a vystavět, budou je vzájemně posuzovat, rozporovat, ba i se budou dohadovat s jediným cílem - nalézt takové řešení federativního uspořádání společného státu, které bude přijatelné pro oba národy. Politickou reprezentaci českého národa však bylo třeba teprve ustavit.

Cíl měl být dosažen podle přijatého ústavního zákona zřízením České národní rady. Zvolená ČNR měla být prozatímním orgánem ústavně politické reprezentace českého národa a měla působit až do ustavení národního státního českého orgánu zvoleného v řádných volbách ${ }^{122}$. Zákon stanovil, že vznikne poněkud svéráznou volbou, nebot' se jí měli účastnit všichni poslanci Národního shromáždění - tedy i poslanci ze slovenských volebních obvodů ${ }^{123}$. Výběr poslanců ČNR se ukázal poněkud obtížnějším krokem, nebot' první návrh kandidátů narychlo vybraných ve vedení strany a Národní fronty poslanci 24. VI. 1968 odmítli. Až napodruhé byla přijata nová kandidátní listina, která lépe odrážela sociální, krajské a genderové složení společnosti, volbám tak již nic nestálo v cestě. Někteří z kandidátů na poslance ČNR se rekrutovali z českých poslanců NS, další byli z řad poslanců národních výborů různých stupňů, jiní reprezentovali společenské organizace nebo kulturní, vědeckou a sportovní sféru, ale žádné poslanecké zkušenosti neměli.

Volba ČNR se uskutečnila 10. VII. 1968, kdy poslanci Národního shromáždění volili 150 jejích členů. Část konzervativních poslanců NS využila skutečnost, že zákonodárný sbor se rozhodl volit tajně, a dvěma kandidátům hlasy nedala, takže nedosáhli potřebného počtu a poslanci zvoleni nebyli. Důvodem byla jejich výrazná proreformní aktivita a také jejich podpisy pod manifestem „Dva tisíce slov“124. Před-

122 Úst. zákon č. $77 / 1968$ Sb., \$ 3.

123 Tamtéž, $\$ 4$, odst. 2, bylo určeno, že volbu provede NS na návrh Národní fronty. F. Cigánek, O. Felcman (vyd.), Národní shromáždění, 3/I, dok. č. 41, s. 283-291.

124 Před volbou ČNR o připravovaném aktu jednalo znovu předsednictvo NS, o volbě poté proveden úřední zápis. Srov. tamtéž, dok. 61 a 62, s. 341-347. Nezvolenými kandidáty na poslance ČNR byli známý cestovatel, spisovatel a fotograf Jiří Hanzelka, a spisovatel, básník a dramatik 
sedou ČNR byl zvolen Čestmír Císař ${ }^{125}$, zvolený na květnovém zasedání ÚV KSČ tajemníkem ústředního výboru strany. Tím byla česká politická reprezentace ustavena a jednání o konkrétní podobě federace mohlo začít. Velmi rychle se ukázalo, že všeobecná shoda na federativní úpravě státu ještě nezajištuje také jednotný př́stup obou národních reprezentací k jeho podobě.

Srpnová okupace proces př́pravy federace sice narušila, ale hektický proces hledání, v němž se střetávaly rozličné koncepce vycházející ze zjevně odlišných názorů české a slovenské reprezentace, pokračoval od konce srpna. Rozdílné př́stupy z jara 1968 zůstávaly, proměňovaly se však, když se dělící linií stávala výstavba federace, způsob jejího utváření a kompetence jejích orgánů. Všeobecná shoda na potřebě federaci vytvořit sice umožnila rychle dospět do fáze ústavního ukotvení její př́ípravy a také principu, že federaci nelze nadekretovat ze shora, ale musí být zformována prostřednictvím národních politických reprezentací a jejich jednání. Poměřování dvou rozdílných koncepcí - slovenskými politiky požadované volnější ustavení federace a českou reprezentací navrhovaná a postupně argumentačně dotvářená její pevnější forma, bylo v pracích na ústavním zákoně dlouho přítomné. Jistý handicap spočívající v nesrovnatelně pozdějším startu a horším materiálním zabezpečení, než tomu bylo u SNR, se dařilo zástupcům ČNR vyrovnávat rychlým propojením s českými členy odborné vládní komise, která na přípravě federace stále pracovala. Na české

Pavel Kohout. - Manifest Dva tisíce slov napsal spisovatel Ludvík Vaculík; jeho text zveřejnily deníky Mladá fronta, Práce a Zemědělské noviny a týdeník Literární noviny 27. VI. 1968. Snahou výzvy bylo povzbudit občany $\mathrm{k}$ výraznější proreformní aktivitě $\mathrm{v}$ politice a společenském životě $\mathrm{v}$ době, kdy část veřejnosti dospívala $\mathrm{k}$ závěru, že vedení KSČ pod tlakem KSSS a dalších komunistických stran socialistických států ustupuje a nedůrazným prosazováním svých záměrů zpomaluje reformní proces. Manifest „Dva tisíce slov“ se stal druhým nejvýraznějším politickým dokumentem obrodného hnutí po Akčním programu KSČ, vytvořeným tentokrát mimo oficiální struktury KSČ. Podepsaly ho desítky osobností z vědeckého, kulturního a sportovního života, schvalovala ho veřejnost, $\mathrm{z}$ politického vedení země se $\mathrm{k}$ němu stavěla relativně vstřícně vláda a nakonec i parlament.

125 PhDr. Čestmír Císař (1920-2013), český komunistický politik a státník, novináŕ, spisovatel, absolvent francouzského gymnázia v Dijonu a Filozofické fakulty UK v Praze. V letech 1963-1965 ministr školství. Pro liberální sklony a všeobecnou oblíbenost ho prezident Novotný z funkce odvolal a poslal jej jako velvyslance do Rumunska. V březnu 1968 byl povolán Dubčekem nazpět a pověřen vedením oddělení školství a vědy ÚV KSČ. Od 1. června do 31. srpna byl opět tajemníkem ÚV, od července 1968 do 1970 předsedou ČNR, krátce byl i poslancem Federálního shromáždění, než byl pro svou účast na reformách z KSČ vyloučen. 
straně se navíc $\mathrm{v}$ diskusích postupně rodila představa o významu české státnosti, jejích politických cílech, $\mathrm{k}$ nimž bezesporu utvoření dvoustranné federace dvou bratrských, avšak početně nestejně velkých národů patřilo ${ }^{126}$. Vedle toho si česká veřejnost chtěla v demokratickém prostředí reformní politiky vyjasnit i nejednoduché aspekty vnitřního charakteru - jedním z nich byl prvek podoby usporádání stojící na uznání zemských tradic. Na Moravě se totiž objevil požadavek uspořádat federaci podle územního principu (propagovala jej vzniklá Společnost pro Moravu a Slezsko, ale zastání měl především na Jihomoravském $\mathrm{KNV})^{127}$, ale podobné názory odmítlo v červenci 1968 předsednictvo parlamentu a do budoucna již nehrály vážnější roli ${ }^{128}$. Složení federace podle zemí by negovalo doposud dosažená dojednání při její př́pravě i princip státoprávní rovnoprávnosti Čechů a Slováků. I v tomto ohledu se potvrzovalo, že limitujícím faktorem zůstával nedostatek času, který komplikoval rychlejší nalézání kompromisu schůdného pro obě strany. Byla to především slovenská politická reprezentace, která naléhala na ukončení prací k 28. X. 1968, nebot' si uvědomovala, že v dané politické situaci by jakákoliv prodleva mohla vyhlášení federace ohrozit ${ }^{129}$. V neposlední řadě překážela skutečnost, že centrální politické vedení bylo až do poloviny ř́ína zcela pohlceno jednáním o smlouvě o pobytu části sovětských vojsk na československém území a př́pravou jejich ubytování.

Smlouva podepsaná předsedy vlád jako mezivládní dohoda a její následné odhlasování v Národním shromáždění 18. X. 1968 znamenaly uznání okupace státního území sovětským vojenským kontingentem ${ }^{130}$. Z hlediska tématu studie ji lze hodno-

126 O počátečním nedostatečně profilovaném povědomí české veřejnosti o nezbytnosti definování vlastní státnosti se zmiňuje M. Bárta v první kapitole syntetizující publikace o roce 1968 a odvolává se na Karla Kosíka. Srov. M. Bárta, Pokus o záchranu reformního programu, [in:] V. Mencl a kol., Československo roku 1968 II, Počátky normalizace, s. 17. Také Z. Jičínský, Vznik ČNR, s. 56-57, konstatuje, že ještě v záŕí 1968 nebyl tento proces u konce.

127 Srov. podrobněji jednak Z. Jičínský, Vznik ČNR, s. 38-47; jednak píše o představách moravských politiků v záležitostech federativního uspořádání státu V. Goněc, $K$ jihomoravským projektům federalizace ( $O$ širším ideovém a politickém pozadí návrhu tzv. trializace), [in:] Pokus o reformu v roce 1968, Banská Bystrica 1999, s. 166-179.

128 Záznam z jednání P-NS 18 VII 1968 edituje publikace F. Cigánek, O. Felcman (vyd.), Národní shromáždèní, 3/1, dok. č. 66, s 364-372. Stanovisko vedení parlamentu je v dok. č. 75, s. 405-406. Veřejnost s ním seznámilo „Rudé Právo“9. VIII. 1968.

129 Obdobně to vidí M. Bárta, Pokus o záchranu, s. 17.

130 Smlouva o dočasném pobytu sovětských vojsk na území Československa neobsahovala článek o délce její platnosti ani možnost na její vypovězení. Představovala navíc podmínku, na níž stál odchod většiny sovětských vojsk i vojsk spojenců - Polska, Mad'arska, Bulharska a NDR. 
tit jako zásadní, bezprecedentní zásah do československé státnosti, jejíž suverenita tím byla silně omezena a tento stav byl pod nátlakem legalizován a legitimizován. O rok později byla srpnová vojenská agrese vydávána za bratrskou pomoc před kontrarevolucí. Ve skutečnosti byla porušením mezinárodní práva, charty OSN i statutu Varšavské smlouvy; Československu, vzápětí federalizovanému, bylo vojenské a politické omezení suverenity vnuceno dlouhodobě ${ }^{131}$. Omezená státní suverenita byla zrušena až v několika krocích po listopadu 1989 - zánikem politické moci KSČ v listopadové revoluci 1989, uzavřením dohody o odsunu vojsk se Sovětským svazem v únoru 1990 a nakonec s etapovitým odchodem sovětských vojsk, ukončeným $\mathrm{v}$ roce $1991^{132}$.

Schválení smlouvy v Národním shromáždění bylo navíc jedním z kroků, jímž se parlament postupně vzdával od záríi 1968 suverenity rozhodování, když rezignoval na právo svobodně hlasovat ${ }^{133}$. Jeho ústavní, formálně stále existující pozice se měla uplatnit ještě při projednávání a poté schválení ústavního zákona o československé federaci, k nimž mělo Národní shromáždění po schválení smlouvy přistoupit. Příprava textu zákona neměla zdaleka ideální podobu.

Koncem zárí byly $k$ dispozici tři osnovy návrhů ústavního zákona, které měl parlament projednávat, a ústavně právní výbor s nimi musel 8. ř́jna při prvním jednání pracovat. Dvě pocházely z ČNR (užší a širší), o jednu se přičinila SNR. Vedle toho pracovala nadále odborná vládní komise. V návrzích se objevovalo několik rozdílů, daných různými názory na způsob jak utvořit federální orgány. Vedle některých odlišností spíše dílčí povahy existovaly dva podstatné. Šlo o způsob vzniku Sněmovny národů (přímá volba občany, delegační volba z obou národních rad), o způsob dovolení obou národních rad na 200 poslanců (opět přímou volbou, nebo doplněním na základě sebevybrání). Konečně ani na rozsah kompetencí výkonných federálních a národních orgánů nebyl shodný pohled. $\mathrm{O}$ všech těchto problémech se vedly diskuse na mnoha grémiích, přičemž poslanci NS nebyli v konečné fázi těmi, kteří by rozhodovali o předložených návrzích a tak stanovili konečnou podobu ústavního

\footnotetext{
131 K tomu M. Potočný, „Vstup“ cizích vojsk do Československa v roce 1968, Mezinárodní vztahy, 1990, č. 4, s. 2-8.

132 Smlouva mezi vládami ČSSR a SSSR o odchodu sovětských vojsk z území ČSSR byla podepsána v Moskvě 26. II. 1990 ministry zahraničních věcí. V platnost vešla ještě týž den. Více M. Potočný, Dohoda o odsunu sovětských vojsk z Československa, Mezinárodní Vztahy, 1990, č. 9, s. 2-12.

133 Proti schválení smlouvy hlasovali čtyři poslanci, deset se jich hlasování zdrželo. Všichni byli za svůj projevený názor později politicky a společensky ostrakizováni.
} 
zákona a tedy i federace. Za nesmírně silného tlaku času - zákon musel být přijat do 28. ř́jna - se rozhodovalo na úrovni vlády a stranického vedení v Praze a Bratislavě. Výsledkem bylo odmítnutí prímých voleb s poukazem na složitou politickou situaci, která bránila vypsat regulérní volby a přijetí delegační formy výběru poslanců. Návrh konečné verze zákona byl podán oběma národními radami, ale $\mathrm{k}$ navrhovatelům se připojila vláda ${ }^{134}$, která fakticky prosadila takové řešení, aby bylo únosné pro panující mocenské poměry. Tato verze byla parlamentem přijata, $\mathrm{i}$ když ještě před plenárním zasedáním mnozí z poslanců kriticky posuzovali fakt, že jim je opět odňata možnost výběru a požaduje se - dokonce s pomocí stranického rozhodnutí, aby hlasovali ve prospěch návrhu zrozeného v prostředí výkonné politické moci ${ }^{135}$.

Závěrečná podoba pưlletého procesu přípravy federativní přestavby společného státu nadešla 27. X. 1968, kdy parlamentní plénum schválilo ústavní zákon o československé federaci ${ }^{136}$. Podle něho se Národní shromáždění nerozpustilo, když z politických důvodů nemohly být volby vypsány, naopak přecházelo do Federálního shromáždění jako jedna z jeho komor - Sněmovna lidu s původním počtem poslanců. Druhou komoru - Sněmovnu národů - měli zvolit ze svých řad poslanci ČNR a poslanci SNR ve shodném počtu 75 poslanců za každou národní radu. Rychle se měnící politická atmosféra v zemi a současně i postupně obnovovaná kontrola stranických byrokratů nad parlamentním životem prostřednictvím stranické skupiny poslanců KSČ potvrzovala návrat politické praxe k předlednovému období. Zákonodárný sbor, ústavně nejvyšší orgán státní moci, se opět vracel do pozice podřízené výkonné moci a vedení KSČ.

Současně byl schválen ústavní zákon o národnostech, který dával národnostním minoritám ústavní práva na svobodný rozvoj a především uznal poprvé od konce druhé světové války opět existenci německy hovořící menšiny v Československu ${ }^{137}$, čímž definitivně uzavřel kapitolu poválečného odsunu německého obyvatelstva.

\footnotetext{
134 Z. Jičínský, Vznik ČNR, s. 66.

135 Diskuse v parlamentních orgánech a grémiích přibližuje edice F. Cigánek, O. Felcman (vyd.), Národní shromáždèní, 3/3, dok. č. 31-33 a 39-40. s. 204-242 a 288-310. O složitosti vyjednávání na půdě obou národních rad a tlaku centra na rychlé ukončení srov. opět Z. Jičínský, Vznik ČNR, s. 55-68.

136 Ústavní zák. č. 143/1968 Sb. o československé federaci vstoupil v platnost 4. XI. 1968 a s různými obměnami trval až do zániku České a Slovenské federativní republiky. Jeho platnost skončila k 1. I. 1993.
}

137 Ústavní zák. č. 144/1968 Sb. o postavení národností v ČSSR vstoupil v platnost 4. XI. 1968 s účinností od 1. I. 1969; zrušen byl k 8. II. 1991. 
Ústavní tečkou za schválením československé federace byl podpis zákona prezidentem republiky armádním generálem Ludvíkem Svobodou, který dokument podepsal na bratislavském hradě 30. X. 1968. Symbolicky tak bylo připomenuto výročí martinské deklarace, jíž se před padesáti lety přihlásili zástupci slovenského národa ke společnému československému státu ${ }^{138}$.

Ústavní zákon výrazně pozměnil dosavadní, všeobecně kritizovanou ústavu z roku 1960, a to tak, že z ní zůstaly jen nevelké zbytky, nebot' většina jejích hlav byla nahrazena textem nového ústavního zákona, který nabyl účinnosti 1. I. 1969.

Československá federace složená ze dvou národních států také v reálný život prvního dne následujícího roku 1969 vstoupila. Mnohé její orgány byly ustaveny sérií zákonů schvalovaných opět narychlo v prosinci 1968, další se rodily postupně. Současně byly národní orgány obou národů doplněny ke stejnému datu o regulérní výkonnou moc - dvě republikové vlády s kompetencemi, které např̀. v oblasti školství a kultury byly výlučné. Přes pozdější úpravy a omezení, vycházející z normalizačních potřeb, se stala federace pro slovenský národ faktickým posunem k dorovnání na úroveň českého národa ${ }^{139}$.

Po půl století trvající existenci se československému státu podařilo vyřešit základní národnostní otázku - poměr mezi Čechy a Slováky. Prošel několika fázemi a nikoliv lehkými peripetiemi ve více obdobích. Vývoj jeho řešení má tři základní fáze. V zakladatelském období státu byl deklaratorně vyhlášen československý národ jako jediný státní národ. Při obnovení státu v roce 1945 byl v Košickém vládním programu Národní fronty uznán slovenský národ jako samostatný a rovnoprávný národu českému. Tato skutečnost byla ukotvena v dílčí slovenské autonomii reflektující význam slovenské role na obnově Československa, avšak již vzápětí poté různě upravované a vždy podřizované potřebám centralisticky rrízeného unitárního státu. Nezměnil to ani komunistický režim, který v roce 1948 stát ovládl, naopak v šedesátých letech slovenskou otázku značně zkomplikoval. V roce 1968 byla provedena federalizace státu, jejímž základem se stala jak slovenská, tak nově uznaná česká státnost. Teprve v této podobě bylo nalezeno demokratické uspořádání vztahů obou tak sobě blíz-

138 Na sklonku roku 1967 bylo ve vedení Národního shromáždění uvažováno o publikaci, která by připomněla padesát let československého státu a československého parlamentarismu, ale srpnová invaze a následná sovětská okupační kontrola politického života v zemi na podzim 1968 nepřipustila jakékoliv připomenutí vzniku svobodné ČSR.

139 Srov. i M. Bárta, Pokus o záchranu, s. 19. 
kých, ale svébytných národů, a konečně dosažena skutečná rovnoprávnost, do té doby často formálně uplatňovaná.

Následná normalizace federalizaci zdeformovala, nebot' státní moc se pod sovětským tlakem znovu obnovila jako nedemokratický systém, v němž společnost neomezeně kontroluje komunistická strana. Kroky politické linie nového Dubčekova vedení KSČ směřující po lednu 1968 k vymanění se ze sovětského byrokratického socialismu a k demokratizaci státní moci zůstaly jen pokusem, jehož šance na reálné prověrení v praxi zastavila srpnová invaze bratrských armád a následná okupace. Obdobně to platilo o snaze parlamentu pozvednout svou úlohu ve státním stroji a zajistit demokratičtější uspořádání společenských poměrů.

Charakter československého státu založeného po skončení první světové války jako parlamentní demokracie se metě demokratické moci znovu na hony vzdálil. Až po sametové revoluci na sklonku roku 1989 se mohla česko-slovenská státnost navracet ke své demokratické podstatě. Její rychlá obnova v následujících měsících však nastolila otázku, zda tento rámec je dostačující pro naplnění národního rozvoje obou národů $\mathrm{v}$ podmínkách obnovené parlamentní demokracie. Postupný a prátelsky provedený rozchod Čechů a Slováků se nakonec stal řešením, akceptovatelným na obou stranách. Československo na sklonku roku 1992 zaniklo.

Nadesłany: 28 IX 2019

Nadesłany po poprawkach: 7 XI 2019

Zaakceptowany: 8 XII 2019

prof. PhDr. Ondřej Felcman, CSc.

ORCID 0000-0003-2706-201X

Univerzita Hradec Králové, Filozofická fakulta

Rokitanského 62

50003 Hradec Králové 3

ondrej.felcman@uhk.cz

PhDr. Tomáš Hradecký, Ph.D.

ORCID 0000-0002-4488-2266

Univerzita Hradec Králové, Filozofická fakulta

Rokitanského 62

50003 Hradec Králové 3

tomas.hradecky@uhk.cz 


\section{Parliament and parliamentarism in building and transforming Czechoslovak statehood}

The authors' intention is to present the activities and operation of the Czechoslovak Parliament - the National Assembly - and to determine the extent of its influence on the origin of the Czechoslovak state, its forms and transformations. With the exception of the German occupation, as the legislature of the Czechoslovak Republic, the National Assembly played an important role in affecting its republican and democratic character, especially during the Interwar period and in a short interval in the 1960s during the Prague Spring in 1968. The study presents these two important stages of the formation of the Czechoslovak state in more detail. In the Interwar period (1918-1938), the Czechoslovak statehood demonstrated features typical of the pluralist parliamentary democracy, respecting party representation of national minorities, with developed parliamentary power since the mid - 1920s. In the period in question, the Parliament was defined as an independent legislature representing an element of democracy in the Czechoslovak Republic. On the other hand, the National Assembly was a centralist body which did not allow disengaging its powers among any regional legislatures. During the period of the First Republic, the disputes over the autonomous elements of the individual countries of Czechoslovakia represented an important crisis of statehood faced by the Parliament. Prior to the Munich crisis, the Parliament was an institution witnessing numerous political discords and disputes but it was never disregarded by any type of superior power or forced to undertake totalitarian activities, as was the case in the 1930s in other Central European parliaments. In the 1960s, a new definition of legislature was coined and announced in 1960 by adopting socialism in Czechoslovakia in a newly ratified socialist constitution. In the constitution, the Communist Party represented the leadership in the state order; at the same time, the Parliament regained its status of the highest echelon of state power. However, in reality its enforcement was guarded by the monopoly of the Communist regime. At the same time, the constitution greatly weakened Slovak autonomy, which, despite all attempts at reinforcement after 1964, represented an imperfect implementation of the legitimate right of the Slovak nation to its own statehood. This requirement was recognized after January 1968 when a radical democratization movement was launched in Czechoslovakia, seeking to create its own humanly-oriented socialist order. To some extent, the reforms of the Prague Spring in 1968 revolved around efforts to create a new form of common statehood between Czechs and Slovaks in the form of a federation. One of the prerequisites for negotiating the form of the federation was official establishment of the Czech statehood with a corresponding political representation in the form of the Czech National Council. 